\title{
GENOCIDE AND BELONGING: PROCESSES OF IMAGINING COMMUNITIES
}

\author{
ADENO ADDIS*
}

\begin{abstract}
Genocide is often referred to as "the crime of crimes." It is a crime that is very high on the nastiness scale. The purpose of the genocidaire is of course to destroy a community - a community that he regards as a threat to his own community, whether the threat is perceived as physical, economic or cultural. The way this takes place and the complicity of law in this process has been extensively explored by scholars. But the process of destroying a community is perversely often simultaneously an "exercise in community building," a process through which intra-communal bonds and belonging are sought to be strengthened. This aspect of genocide has been entirely neglected by scholars, especially the role of law in that process. This article makes and defends two claims about communities and belonging in relation to genocide. First, it argues that as perverse as it sounds, genocide is in fact an exercise in community building and law is highly implicated in that process. It defends the thesis with arguments that are conceptual as well as empirical. The second, and more hopeful, claim is that the international response

* W. R. Irby Chair and W. Ray Forrester Professor of Public and Constitutional Law, Tulane University School of Law. Previous drafts of the paper were presented at an international conference at the Guanghua Law School of Zhejiang University (China) and at Tulane Law School faculty symposium. I thank participants at those meetings for the many helpful questions and comments. Special thanks go to Nicholas Almendares, Onnig Dombalagian, Adam Feibelman, Marjorie Kornhauser, Shu-Yi Oei, Vernon V. Palmer, Asif H Qureshi, Keith Werhan, and Siegfried Wiessner. And I thank Victoria McIntyre of Tulane Law School for excellent research assistance.
\end{abstract}


to prevent genocide or to punish genocidaires is itself a process in community building, a way of imagining a version of the international community, and a counter to the genocidaire's vision of a pure and superior community. Using two international legal doctrines-universal jurisdiction and the Responsibility to Protect (R2P) - the article shows that international responses to genocide are not simply instrumental (preventing and punishing genocide), but that they have constitutive dimensions as well. The international community that is imagined through these two doctrines is one that is diverse and vulnerable. Put simply, this article is about how communities are imagined both in their destructive and constitutive sense.

Keywords: belonging, community, genocide, human rights, international crimes, jurisprudence, responsibility to protect, universal jurisdiction 


\section{TABLE OF CONTENTS}

1. Introduction: The Issue-Genocide and Belonging ........... 1044

2. Genocide: A (Not So) Brief Outline ..................................... 1050

3. Genocide and the Process of Imagining Communities ..... 1057

3.1. Communities and Positive Sentiments............................ 1057

3.2. Communities and Consequences ..................................... 1058

4. Genocide, Law and Belonging ….......................................... 1065

5. International Response to Genocide: Imagining the

International Community ..................................................... 1071

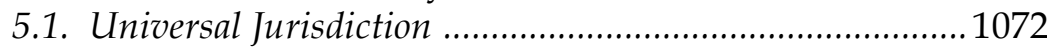

5.2. Responsibility to Protect $(R 2 P)$........................................ 1074

5.3. Universal Jurisdiction and R2P: Comparison and

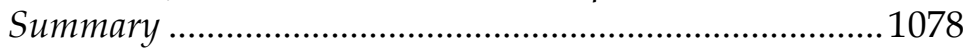

5.4. What Makes Genocide an Offense Eligible for R2P and Universal Jurisdiction: Current Accounts ....................... 1080

5.4.1. Genocide "Shocks" the Conscience......................... 1080

5.4.2. Genocide and Chaos.............................................. 1084

5.5. International Response to Genocide: Ways of Imagining the International Community. 1086

5.5.1. Homo Sapiens and Nature: A Way of Imagining the International Community?. 1088

5.5.2. The International Community and the Outlaw OtherAnother Way of Imagining the International Community 1089

5.5.2.1. The International Community and Secondary Responsibility 1089

5.5.2.2. Hostis Humani Generis: The Genocidaire as the Enemy of All of Us 1091

5.5.2.3. Diversity and Vulnerability.... 1094

5.5.2.4. Defining (Imagining) the International Community From Above and From Below 1095

6. The International Community and Genocide Watch: Responsibility to Protect and Civil Society...................................... 1104

7. Conclusion 1109 


\section{INTRODUCTION: THE ISSUE-GENOCIDE AND BELONGING}

One of the most important questions in the globalized world in which we live is the issue of belonging. Of course, belonging has always been an important issue, for to belong is a fundamental human quest. ${ }^{1}$ One's identity, an indispensable feature of one's life, is tied to what, to whom and how one belongs. ${ }^{2}$

Although the quest for belonging has always been with us, the issue has recently emerged with more intensity and urgency. There are at least two reasons why the issue has currently become a pressing issue. First, globalization has increasingly destabilized traditional (generally accepted) forms of belonging and units to which one belongs. The manner in which boundaries are drawn and the very issue of what constitutes a boundary and a community are constantly changing. ${ }^{3}$ This has led many to worry as to where and how they belong. Indeed, globalization has led to two seemingly contradictory tendencies. On the one hand, there is a visible move to forming greater or larger unions among political units, either on a comprehensive or limited basis. Although currently under considerable

1 Roger Cohen, The Quest to Belong, N.Y. TIMES, Nov. 29, 2013, at A39, http:// www.nytimes.com/2013/11/29/opinion/cohen-the-quest-to-belong.html [https://perma.cc/XMG4-SQ7H]

("If you dig into people who are depressed, you often find that their distress at some level is linked to a sense of not fitting in, an anxiety about where they belong: displacement anguish.").

2 See William E. CONNOlly, IDENTITY \DifFERENCE: DemOCRATIC NeGOTIATIONS OF POLITICAL PARADOX 158 (1991) ("Identity, in some modality or other, is an indispensable feature of human life").

3 Adeno Addis, Community and Jurisdictional Authority, in BEYOND EXTRATERRITORIALITY: TRANSNATIONAL LEGAL AUTHORITY IN AN AGE OF GLOBALIZATION 32 (Gunther Handl, Joachim Zekoll and Peer Zumbansen eds. 2012) ("Indeed, in the era of globalization, the process of continuous change may be one of the most salient and most permanent features of communities."). See Adeno Addis, Imagining the Homeland from Afar: Community and Peoplehood in the Age of the Diaspora, 45 VAND. J. TRANSNAT'L L. 963, 1039-40 (2012) (arguing that boundaries that form communities are not necessarily territorial and they often overlap). Idriss Fofana, A Crisis of Belonging, HARV. INT'L REV. 34, 34 (2009) ("Relations between Rwanda and the DRC [Democratic Republic of Congo] have been long affected by a crisis of belonging among ethnic Rwandans in the eastern DRC. Since the early colonial times, the Kivu Provinces have served as the refuge of choice for the losers of Rwanda's brutal power policies. Every new large migration into DRC has raised the question of who among the country's many ethnic Rwandans should count as Congolese."). 
stress, the European Union is one obvious example of a comprehensive union. By "comprehensive union" I refer to a union across many areas - economic, political, monetary, defense, etc. But there are other unions that are limited to specific areas of life. One example is the World Trade Organization (WTO) whose primary function is said to be one of ensuring free and orderly trade among states. The desire for forming larger unions is informed by the fact that many issues - e.g. economic, security, and environmental-are increasingly proving to be beyond the capacity of one state, even a relatively powerful one, to deal with. ${ }^{4}$

On the other hand, globalization seems also to lead to more fragmentation where groups (ethnic, linguistic, racial, religious) seek to reassert their "local" (as opposed to "national") identities as more secure sources of belonging in this globalized world of uncertainty or, to borrow a phrase from W.H. Auden, in "an age of anxiety." 5 The most virulent attempts to slow down the speed of globalization have taken the forms of religious and ethnic fundamentalism. ${ }^{6}$

I think the late great anthropologist, Clifford Geertz, was correct in his observation that the world is "growing both more global and more divided, more thoroughly interconnected and more intricately partitioned, at the same time. As the one increases, so does the other." 7 One does not need to agree with Geertz that there is a oneto-one correlation between interconnection and partition to embrace his general point that interconnection and partition have defined globalization. This, of course, makes the issues of identity and belonging rather complicated and an important subject of inquiry. ${ }^{8}$

4 The idea that even a powerful state needs legal cooperation and coordination to deal with global problems that affect it was expressed long ago by Hugo Grotius. See Hugo Grotius, The LaW OF WAR AND PeAce 9 (Louise R Loomis trans., Walter J. Black Inc. 1949) (1625) (“[T]here is no state so strong that it may not some time need the help of others outside itself, either for purposes of trade or to defend itself against the combined hosts of a number of other nations joined against it.").

5 W. H. Auden, The Age of Anxiety, in COLLECTED POEMs 447 (Edward Mendelson ed., First Vintage Int'1 Ed. 1991) (1976).

6 William Connolly, Speed, Concentric Cultures, and Cosmopolitanism, 28 POL. THEORY 596, 598 (2000).

7 Clifford Geertz, Available Light: Anthropological Reflection on PHILOSOPHICAL TOPICS 246 (1998).

8 Sheila L. Croucher, Globalization and Belonging: The Politics of IDENTITY IN A CHANGING WORLD 35 (2004) (" [S]o much of the subject matter that currently consumes scholars and politicians can be characterized in relation to questions of belonging and identity. Conflicts in the former Yugoslavia, the Middle East, Northern Ireland, and Rwanda, while profoundly complicated in their origins and contemporary manifestations, are poignant examples of the power and passion that 
Second, new communication technologies - especially the Internet and satellite television - have enabled individuals to cultivate forms of belonging and membership that could not have been possible or even imagined a few years ago. Alternative forms of belonging have opened up the possibility of multiple and overlapping communities to which one may belong. The consequence of this is the emergence of overlapping and ambiguous identities. But there is another, often darker side to the communication revolution: It has enabled people to think of the purity of communities. We tailor our communities in the same way that we tailor the information we seek to consume. ${ }^{9}$ Indeed, the two cultivate one another. "People live separately together," explained a Rwandan soldier discussing the ambiguous relationship among Rwandans in the aftermath of the genocide.10 The idea of the purity of communities has often been the prelude to the elimination of those who are thought to make those communities impure. There is yet another dark side of the communication revolution. It enables members of perpetrator communities to destroy their victim communities more quickly and more efficiently so as to establish their "pure" communities rather quickly.

\footnotetext{
surround belonging."). Technically, "belonging" and "identity" refer to two different states of affairs. "Belonging" refers to the act or process of joining the "Us" while identity relies on the existence of the "Other." That is, "belonging" needs an "Us" and identity a "Them." But there is no way of thinking about an "Us" without simultaneously thinking about a "Them." Therefore, identity and belonging cover the same area (boundary) but from different angles or starting points.

9 To see how many Americans are simply seeking "facts" with which they agree and listening to or associating mostly only with those with whom they have ideological affinity, see Amy Mitchell, et. al., Political Polarization $\mathcal{E}$ Media Habits, PEW RESEARCH CENTER (Oct. 21, 2014), http://www.journalism.org/2014/10/21/political-polarization-media-habits/

[https:// perma.cc/YCT8-R9R4]; Rem Rieder, Just the "Facts," Please, U.S.A. TODAY, Oct. 21, 2014, at 2B, http://www.usatoday.com/story/money/columnist/rieder/2014/10/21/polarized-media-habits-among-liberals-conservatives/17619635/ [https://perma.cc/GPG9-HUXN].

10 Philip Gourevitch, We Wish to Inform You Tomorrow We WiLl Be Killed WiTH OUR FAMILIES 34 (1998).
} 
After all, what made the Rwandan genocide so efficient was the ability of Hutus to communicate and coordinate quickly and widely during the genocide. ${ }^{11}$ Communication speed compresses space. ${ }^{12}$

Using the crime of genocide as the focus of the inquiry, this article makes and defends two claims about communities and belonging. First, it argues that as perverse as it sounds, the crime of genocide is an "exercise in community building." 13 Often, when we think about communities we think of positive sentiments, but common criminality is also a form of building solidarity and community. The obvious example is the formation of gangs, but it happens in grave circumstances involving mass atrocities as well. The community

11 Philip Gourevitch described the Rwanda genocide as "the most efficient mass killing since the atomic bombings of Hiroshima and Nagasaki." GOUREVITCH, supra note 10, at 3 . Mass communication was used to identify the places that Tutsis were hiding and to communicate to perpetrators how to get to them. Samantha Power, Bystanders to Genocide, THE ATLANTIC, Sep. 2001, at 17, http:/ / www.theatlantic.com/magazine/archive/2001/09/bystanders-to-genocide/304571/

[https://perma.cc/Q8NU-NRL7] ("[L]ists of [Tutsi] targets had been prepared in advance, and Radio Mille Collines broadcast names, addresses, and even licenseplate numbers. Killers often carried a machete in one hand and a transistor radio in the other."). There is of course another aspect of the role of communication in the genocidal acts that I shall not explore here. The Rwanda genocide was at least partly instigated by Hutu radio propaganda that continuously depicted Tutsis as the evil that had brought untold misery on the Hutu community. Prosecutor v. Nahimana, Case No. ICTR 99-52-T, Judgement and Sentence, 『1031 (Dec. 3, 2003), http://unictr.unmict.org/sites/unictr.org/files/case-documents/ictr-99-52/trialjudgements/en/031203.pdf [https://perma.cc/NG4J-XTZX] ("RTML broadcasting was a drumbeat, calling on listeners to take action against the enemy. ... The nature of radio transmission made RTML, particularly dangerous and harmful, as did the breadth of its reach."). The issue of how much of such propaganda should be tolerated is often a difficult issue for severely fractured societies. For the issue as to if and when such propaganda should be restricted, see Joshua Wallenstein, Punishing Words: An Analysis of the Necessity of the Element of Causation in Prosecutions for Incitement to Genocide, 54 STAN. L. REV. 351, 388-97 (2001) (explaining that the propaganda must cause direct and public incitement to commit genocide); Marlise Simons, Trial Centers on Role of Press During Rwanda Massacre, N.Y. TIMES, March 2, 2002, http://www.nytimes.com/2002/03/03/world/trial-centers-on-role-ofpress-during-rwanda-massacre.html [https://perma.cc/C6R5-TU5Y] (explaining at what point political propaganda become criminal).

12 Connolly, Speed, Concentric Cultures, and Cosmopolitanism, supra note 6, at 597-98. Connolly relies on Paul Virilio's work to make the observation that "[when] speed accelerates, space is compressed."

13 GOUREVITCH, supra note 10 , at 95. I must note here that the argument that genocide is an exercise in community building is not meant to suggest that that is the only or exclusive purpose for which genocide is committed. That, of course, cannot be. There are multiple other purposes - such as social or political powerthat are motivators of genocidaires. The argument, however, is that the notion of community is one factor and perhaps the factor that underlies many of these other purposes. 
"that slays together stays together." 14 And in a world of dislocation and anxiety, atrocities such as genocide may, in the future, occur more frequently than we imagine. ${ }^{15}$ Furthermore, perhaps contrary to most people's intuitions, the argument in this article is that genocide does not occur in a world of no-law, but is in fact often preceded by all sorts of law that marks the target as different and prepares its elimination. Recognizing this fact, I shall argue later, will ensure that we know what and when we should monitor to prevent genocidal breaks.

The second, and the more positive, at least the more hopeful, claim that the article makes and defends is this: if genocide is a (perverse) process in community building, then the international response to it, either to forestall it or to punish perpetrators, is also a way (perhaps a test) of how we imagine the contours of the international community, the community of humankind. ${ }^{16}$ The article will

14 See David Cesarani, Book Review, 45 CENT. Eur. Hist. 162 (2012) (reviewing Thomas KÜHNe, BelongING AND GenOCIDE: HitleR's COMMUNITY, 1918-1945 (2010)). Cesarani expresses Kühne's thesis this way: “The nation that slays together, stays together."

15 What one sees in several African countries and the Middle East (especially the Middle East) is that the nation-state is fragmenting along ethnic and religious lines. See Liz Sly, How the Battle Against the Islamic State is Redrawing the Map of the Middle East, WASH. POST, Dec. 30, 2015, at A1, https://www.washingtonpost.com/world/on-the-front-lines-of-the-war-against-the-islamic-state-a-tangled-web/2015/12/30/d944925a-9244-11e5-befa-99ceebcbb272_story.html [https://perma.cc/KA8F-CVDC]. And as a consequence, the threat of ethnic cleansing and genocide are ever present. What ISIS and al Qaeda have been doing to religious and ethnic minorities in Iraq and Syria is a clear example of the genocidal threat that follows the breakups of nation-states. See, e.g., Nursa Front Targets Syria Druse Minority, THE WALL ST. J., June 12, 2015, at A8 ("Sunni Islamist groups in Syria and Iraq such as Islamic State have targeted Druse, Yazidi and Christian minorities as well as Shiite Muslims and Syrian President Bashir al-Assad's Shiitelinked Alawite sect as sectarian-fueled fighting rages across both countries."); Chip Carey, Syria's Civil War Has Become a Genocide, WORLD POLICY BlOG (Sept. 16, 2013 12:00 AM); Mark Levene, Genocidal Legacies of the Great War: Legacies of 1914, 113 Current Hist. 318, 318 (2014); Matthew Krain, J'accuse! Does Naming and Shaming Perpetrators Reduce the Severity of Genocides or Politicides? 56 INT'L STUD. Q. 574, 574 (2012) ("Genocides and politicides, atrocities unparalleled in humanity, were regular features of the international political landscape of the twentieth century. There is no reason to expect that they will cease to be recurrent problems in the twentyfirst century") (citations omitted).

16 Let me at the outset note that the claim that I shall make in this article that outside responses to genocide (whether the response is multilateral or unilateral) are ways of imagining the international community is not to suggest that that is the only way people understand or should understand what the phrase "international community" means. There are multiple ways in which the notion of "the international community" is understood; the one that this article advocates is simply one way of thinking about the international community. For various ways in which the 
explore this second thesis using two international legal doctrines universal jurisdiction and the Responsibility to Protect (R2P) which have been adopted to deal with mass atrocities or grave crimes. The two doctrines are the two ends of the spectrum of what I shall call a shared responsibility ${ }^{17}$ to protect people from mass atrocities (R2P) and to punish perpetrators of such atrocities (universal jurisdiction). So, to put it simply, this article is about how communities are imagined both in their destructive and constitutive sense and what we may need to do to minimize the destructive tendencies and enhance the affirmative and positive dimensions.

The article is organized in the following manner. Section 2 introduces the crime of genocide and how it is legally defined both as a matter of conventional and customary law. In the process, the section notes that there is an international consensus on the need to fight this "crime of crimes," as it is often referred to, both at the national and international level. Section 3 develops the argument that genocide is a process of community building and responds to potential critics who may view the idea of associating genocide with any notion of community implausible or even perverse. Section 4 makes the argument, perhaps against many people's intuitions, that genocide does not occur when law does not function, rather genocide and other mass crimes are often preceded by and their occurrences facilitated by all sorts of law. Section 5, which forms the heart of the article, explores the proposition that the international responses to genocide-represented by R2P and universal jurisdiction - are not simply instrumental (preventing or punishing genocide), but also have constitutive dimensions. They are partly processes through which the identity of the international community is imagined. The section asserts and defends the proposition that the international community so imagined is a community that is diverse and vulnerable. Section 6 explores the relationship between genocide and another part of the international community, international civil society. The role of civil society in monitoring and reporting on possible or actual genocide is crucial in how effectively national or international public institutions respond to threats of genocide or punishing genocidaires.

notion of the international community has been understood see William E. Conklin, The Exclusionary Boundary of the Early Modern International Community, 81 NORDIC J. INT'L L. 133 (2012).

17 For the idea of shared responsibility, see infra pages $45-46$. 
Section 7, the concluding section, is a backward glance highlighting some of the arguments made in the article. Specifically, it notes that when the international community responds to the threat of the "very existence of certain human groups" and when it punishes those who have perpetrated the crime of genocide, it endorses "the most elementary principles" that are the foundation of an international community: a community of diverse peoples who are united in their very humanity and vulnerability. When we take responsibility for the genocidal crimes of others through declarations such as "genocide is a crime against all of us" and make the perpetrators accountable for those crimes through the doctrines of universal jurisdiction and $\mathrm{R} 2 \mathrm{P}$ we imagine or constitute "humanity." When we "share the onus of evil committed by others," we "become members of humanity." 18 The Conclusion adds that if genocide is an attack on all of us, as international law provides, then not to respond to genocidal attacks or threatened attacks is to bring into question the validity or sincerity of that legal claim and even more to send a signal to others that genocidal attacks can go on with impunity. That point was not lost on Adolf Hitler. ${ }^{19}$

Before I explore the issue of genocide as a process of community building and the international response to it as a way of imagining the international community, in the next section I will briefly outline what the crime of genocide entails.

\section{GENOCIDE: A (Not SO) BRIEF OUTLINE}

Referred to as the "crime of crimes," 20 genocide is regarded as the gravest of international crimes. ${ }^{21}$ It is prohibited by both conventional and customary law. In terms of conventional law, the

18 David Luban, Arendt on the Crime of Crimes, 28 RATIO JuRIS 307, 320 (2015).

19 See infra note 225 and the text accompanying it.

20 See William A. Schabas, Genocide in InTernational Law: The Crime of CRIMES 227 (2d ed. 2009). Prosecutor v. Rutaganda, Case No. ICTR 96-3-T, Judgement and Sentence, ๆ 451 (Dec. 6, 1999) ("[T]he Chamber is of the opinion that genocide constitutes the 'crime of crimes', which must be taken into account when deciding the sentence.").

21 The term "genocide" is made up of the Greek genos which means race or tribe and the Latin cide which refers to killing. The term "genocide" was coined by Raphael Lemkin, a Polish Jewish lawyer who lost his entire family except his brother in the Holocaust. Lemkin, a refugee from Poland, worked in the United 
Convention on Genocide is the point of departure. In its preamble, the Convention makes the obvious historical observation that "at all periods of history genocide has inflicted great losses on humanity." 22 Giving confirmation to that assertion, Ben Kiernan in an outstanding study has explored the costs of genocide on humanity from classical Greece down to the last known genocide of the $21^{\text {st }}$ century. ${ }^{23}$

Article II of that Genocide Convention defines genocide as engaging in certain acts such as killing and causing serious bodily injury that target listed protected groups "with the intent to destroy, in whole or in part," those groups. ${ }^{24}$ Members of the targeted group are marked or chosen on the basis of their group membership. This definition is reproduced in the statutes of the two well-known ad hoc Tribunals established by the Security Council of the United Nations ${ }^{25}$ as well as the Rome Statute that established the International

States War Department. RAPHAEL LEMKIN, AxIs Rule IN OCCUPIED EuROPE: LAWS OF OCCUPATION, ANALYSIS OF GOVERNMENT, PROPOSAls FOR REDRESS (1944).

22 Convention on Prevention and Punishment of Crime of Genocide pmbl., Dec. 9, 1948, 78 U.N.T.S. 277 [hereinafter Convention on Genocide].

23 See Ben Kiernan, Blood and SoIl: A World History of Genocide AND EXTERMINATION FROM SPARTA TO DARFUR (2007) (examining genocide incidents from the classical era to the present, focusing on worldwide colonial exterminations and twentieth-century case studies including the Armenian genocide, the Nazi Holocaust, Stalin's mass murders, and the Cambodian and Rwandan genocides). As I shall indicate later, the term "genocide" was coined in early twentieth century and Kiernan is affixing retroactively that label on earlier events. For many of the events he describes, the label genocide fits well, but not for all.

24 See Convention on Genocide, supra note 22, at art. 2.

Article II provides:

"In the present Convention, genocide means any of the following acts committed with intent to destroy, in whole or in part, a national, ethnic, racial or religious group, as such:

a. Killing members of the group;

b. Causing serious bodily or mental harm to members of the group;

c. Deliberately inflicting on the group conditions of life calculated to bring about its physical destruction in whole or in part;

d. Imposing measures intended to prevent births within the group;

e. Forcibly transferring children of the group to another group."

As it is clear from the definition, genocide has physical element (the actus reus) and the mental element (mens rea). The mental element has two aspects to it: a narrow intent (to do the specific physical harms) and the broader intent (to destroy the group as such). The narrow intent is in the service of the broader intent. Both aspects of the intent have to be present for there to be the crime of genocide.

25 See Statute of the International Criminal Tribunal for the Former Yugoslavia since 1991, at art. 4, U.N. Doc. S/RES/827, 33 I.L.M. 1602 (1993) available at http://www.icty.org/x/file/Legal\%20Library/Statute/statute_sept09_en.pdf 
Criminal Court. ${ }^{26}$ As Article I of the Convention provides, genocide may be committed in times of war or peace ${ }^{27}$ and it requires no state action. 28

Genocide is also prohibited under customary international law. Indeed, the prohibition of genocide is on the list of peremptory norms (jus cogens) ${ }^{29}$ whose violators are referred to as hostis humani generis (enemies of humankind). ${ }^{30}$ Various international tribunals have affirmed the view that the crime of genocide is prohibited under customary international law. Thus, the International Court of Justice in Case Concerning Armed Activities on the Territory of the Congo (Democratic Republic of the Congo v. Rwanda) 31 and the International Criminal Tribunal for Rwanda in several cases ${ }^{32}$ have both concluded that the prohibition of genocide is most certainly a principle

[https://perma.cc/2VUZ-4F2N] (defining genocide and the acts punishable as such); Statute of the International Criminal Tribunal for Rwanda, at art. 2, U.N. Doc. S/RES/955, 32 I.L.M. II92, (1994) available at http://www.securitycouncilreport.org/atf/cf/\%7B65BFCF9B-6D27-4E9C-8CD3-

CF6E4FF96FF9\%7D/IJ\%20SRES955.pdf [https://perma.cc/YD4M-YHWS] (defining genocide and the acts punishable as such).

26 Rome Statute of the International Criminal Court, art. 6, July 17, 1998, U.N. Doc. A/CONF.183/9 (1998), 37 I.L.M. 999 [hereinafter Rome Statute], available at https://www.icc-cpi.int/nr/rdonlyres/ea9aeff7-5752-4f84-be940a655eb30e16/0/rome_statute_english.pdf [https:// perma.cc/N9B3-C8CM].

27 Convention on Genocide, supra note 22, at art. 1 ("The Contracting Parties confirm that genocide, whether committed in time of peace or in time of war, is a crime under international law which they undertake to prevent and to punish.").

28 Id. at art. 4.

29 See Case Concerning Armed Activities on the Territory of the Congo (Dem. Rep. Congo v. Rwanda), Judgment, 2006 I.C.J 6, 31-32 94 (Feb. 3) [hereinafter Armed Activities in Congo] ("the principles underlying the [Genocide] Convention are principles which are recognized by civilized nations as binding on States, even without any conventional obligation"); see also RESTATEMENT (THIRD) OF THE FOREIGN RELATIONS LAW OF THE UNITED STATES, § $702 \mathrm{cmt}$ (showing how the prohibition against genocide is recognized as customary international law).

30 Id. (quoting Filartiga v. Pena-Irala, 630 F.2d 876, 890 (2d Cir. 1980)).

31 Armed Activities in Congo, supra note 29 at 161; see also Reservations to the Convention on Prevention and Punishment of the Crime of Genocide, Advisory Opinion 1951 I.C.J. 15, 23 (May 28) ("[T]he principles underlying the Convention are principles which are recognized by civilized nations as binding on States, even without any conventional obligation.").

32 See Prosecutor v. Kayishema, Case No. ICTR 95-1-T, Judgment, ๆ 88, (May $21,1999)$ ("[T] he crime of genocide is considered part of international customary law and, moreover, a norm of jus cogens."); Prosecutor v. Rutaganda, Case No. ICTR 96-3-T, Judgment and Sentence, If 46 (Dec. 6, 1999) ("The Genocide Convention is undeniably considered part of customary international law ...."). 
of customary international law. Several nation-states have also enacted legislation on the suppression and prosecution of genocidal crimes, more or less adopting the international definition of the crime $^{33}$, which of course strengthens the argument that genocide is indeed a crime under customary international law.

However, even with such international consensus about the gravity of the crime and the commitment on the part of the international community to prevent and punish, genocide continues to occur. ${ }^{34}$ More than 100,000 Hutus perished in Burundi in 1972. The International Court has concluded that genocide was committed during the Balkan conflicts in the 1990s. ${ }^{35}$ And, of course, the most efficient genocide occurred more recently in Rwanda, a genocide that resulted in the murder of about 800,000 people (mainly Tutsis) in less than 100 days ${ }^{36}$ - slaughtered by Hutus, not just militants, but "ordinary" Hutus. ${ }^{37}$ It is the ordinary face of evil that often shocks us, for we expect evil to appear in different, monstrous forms. ${ }^{38}$ It is

33 See SCHABAS, supra note 20, at 5 ("A large number of States have enacted legislation concerning the prosecution and suppression of genocide, mostly by amending their penal or criminal code in order to add a distinct offense.").

34 Bradley Campbell, Genocide as Social Control, 27 SOC. THEORY 150, 151 (2009).

35 See Application of the Convention on the Prevention and Punishment of the Crime of Genocide (Croatia v. Serbia), Judgment, 2015 I.C.J. 118, at 376 (Feb. 3); Martin Mennecke, Genocidal Violence in the Former Yugoslavia: Bosnia Herzegovina, in CENTURIES OF GENOCIDE: ESSAYS AND EYEWITNESSES ACCOUNTS 477, 495 (Samuel Totten \& William S. Parsons eds., 4th ed. 2013).

36 Gourevitch, supra note 10, at 133 ("Take the best estimate: eight hundred thousand killed in a hundred days. That's three hundred and thirty-three and a third murder an hour-or five and a half lives terminated every minute."); KIERNAN, supra note 23, at 559 (" $[\mathrm{H}]$ alf a million to 1 million people [were] murdered in just three or four months.").

37 A Seventh-Day Adventist pastor, Catholic nuns, a female government minister who was in charge of family issues and family welfare, a mayor on whom many relied to give them protection, etc. were accused and convicted of genocide. Gourevitch makes the point this way: "Neighbors hacked neighbors to death in their homes, and colleagues hacked colleagues to death in their workplaces. Priests killed their parishioners, elementary-school teachers killed their students." Philip Gourevitch, Letter From Rwanda: After the Genocide, THE NEW YORKER, Dec. 18, 1995, at 3, http://www.newyorker.com/magazine/1995/12/18after-the-genocide [https:/ / perma.cc/YB4G-QNT9].

38 See Saira Mohamed, Of Monsters and Men: Perpetrator Trauma and Matt Atrocity, 115 COLUM. L. REV. 1157, 1165, 1208-1215 (2015) ("We are expected to see perpetrators as different, and courts and observers treat them as different. But perpetrators are not simply monsters ... . Acknowledging their humanity might be alarming; it forces us to reckon with the idea that, if they are capable of committing these horrors, then perhaps we all might be able to do the same."). In other words, viewing perpetrators of crimes like genocide as uniquely monstrous allows us to shield ourselves from the horrible thought that we might be capable of committing 
to capture and highlight the ordinary face of evil, the fact that the great evils in history, including the Holocaust, were executed not by fanatics and psychopaths but by ordinary people that Hannah Arendt subtitled her report on the trial of Eichmann in Jerusalem as a "Report on the Banality of Evil." 39

Even more worryingly, there are a number of countries that are or ought to be on genocide watch ${ }^{40}$, for there are deep ethnic or religious-based fractures which can, at any time, ignite into a full-scale genocide and ethnic cleansing. ${ }^{41}$ The United Nations Secretary-General was perhaps a bit too pessimistic, but he had a point when he

such horrendous crimes. It is, as Mohamed sees it, "a comforting message." Id. at 1211.

39 See HANNAH ARENDT, EICHMANN IN JERUSALEM: A REPORT ON THE BANALITY OF EVIL (1963) (observing that that Eichmann was not a fanatic or psychopath, but an extremely average person who relied on clichéd defenses rather than thinking for himself and was motivated by professional promotion rather than ideology).; see also GEORGES BATAILLE, EROTICISM 186 (Mary Dalwood trans., 1987) (noting that despite many people's desire to distinguish between the civilized "us" and those other "barbarians," "observation shows that the same peoples are alternatively barbarous and civilized in their attitude ... . [A]ll civilized men are capable of savagery."); see also Dan Stone, Genocide as Transgression, 7 EUR. J. SOC. THEORY 45, 46 (2004) ("Academics believe that they have seen thorough [the] Hollywood misrepresentation, and know that, in reality, the horror of the Holocaust consists not in the fact that the murderers were so ' mad, so bestial, driven by blood lust, but in the fact that the murderers were frighteningly like ourselves. The machinery of destruction meant that people could be 'disposed of' by 'desk-killers' like Eichmann, in a clam, industrial, production-line system of death."). Stone faults academics who think thusly for implying that "the mere use of technology with the absence of passion." Id. at 47.

40 A good example is the Central African Republic where there has been serious sectarian violence (Muslims v. Christians) which a senior United Nations official characterized as being "the seeds of a genocide." Somini Sengupta, High Bloodshed Amid Ghosts of Rwanda and Bosnia, N. Y. Times, Dec. 10, 2013, at A5, http:/ / www.nytimes.com/2013/12/10/world/africa/stopping-bloodshed-inthe-central-african-republic-amid-ghosts-of-genocide.html

[https:// perma.cc/8GCK-TUJ9]. But there are many others, perhaps even including Burundi. There is currently an electoral crisis in Burundi that is displacing tens of thousands people and sending them to neighboring countries. As the Washington Post in its editorial noted, the "political crisis could devolve into tragic reprise of ethnic conflict between Burundi's Hutu majority and Tutsi minority." An Electoral Crisis in Burundi, Wash. Post, May 9, 2015, https://www.washingtonpost.com/opinions/an-electoral-crisis-in-burundi/2015/05/09/6d7a1e7e-

f581-11e4-b2f3-af5479e6bbdd_story.html?utm_term=.b1e8549e6945 [https:// perma.cc/SP53-YZL6].

41 Ethnic cleansing is "the forced displacement" of civilians. Application of Convention on Prevention and Punishment of Crime of Genocide (Bosn. \& Herz. v. Serb. and Montenegro), Judgment 2007 I.C.J. 43, 64 at 161 (Feb. 26). By that definition, what happened to Native American in the early years of the Republic was 
observed that "[n]o part of the world can consider itself immune to the risk of genocide." 42

The destructive dimension of genocide is apparent to all, but what I shall claim here is that there is another, constitutive (perverse, to be sure) dimension to which scholars have not paid sufficient attention. An understanding of this phenomenon I claim will enable us to respond to the threats of genocide more effectively, for we will better understand the conditions that lead to genocidal events.

In his detailed and lucid account of the Rwanda Genocide, Philip Gourevitch makes the rather arresting but unexplained and passing observation that "[g]enocide, after all is an exercise in community building." 43 Many will surely dispute this statement on at least two grounds. First, critics may resist the notion that communities can be defined by other than positive sentiments. Second, skeptics may view a "chicken and egg" problem in the assertion. Which came first, the community or the genocide? The critique here is that genocide is simply a consequence of existing conflicting communities rather than a condition giving rise to communities. People engage in acts of genocide, critics may argue, because they believe that the community to which they have imagined to belong can only be sustained through a form of purification - the removal of the Other from one's presence.

In the next section, I shall first argue that these challenges are misplaced and then go on to develop an argument that supports the proposition that genocide, as perverse as it is, is indeed an exercise in community building and a process of firming up a particular understanding of belonging. Genocide is a pivotal event which is both a consequence and a cause of imagining communities in a certain

indeed ethnic cleansing. See KIERNAN, supra note 23, at 320, 327 (“Over time, [President] Jefferson's project for Indians ranged widely, from a peaceable assimilation with white America farmers to what we would now call ethnic 'cleansing' of Indians, first in wartime, then in peace, and extending to extermination if he deemed it necessary."). Although the term "ethnic cleansing" entered popular consciousness during the Balkan wars of the 1990s, it was apparently coined by the Nazis in 1939_ 40. See id. at 440 ("In 1939-40, Hitler and other leading Nazis coined the term ethnic cleansing (völkische Flurbereinigung). The 'cleansed' occupied areas of Jews and were obsessed with the concept of racial "purity.").

42 Ban Ki-moon, U.N. Secretary-General, Remarks at the International Conference on the Prevention of Genocide (April 1, 2014) (transcript available at http://www.un.org/sg/statements/index.asp?nid=7555 [https:/ / perma.cc/G688-NKYX]).

43 Gourevitch, supra note 10, at 95. The statement was not explained or developed. It appeared to be a throwaway observation. 
way. To be sure, the community imagined is perversely premised on the negation of the very existence of the target community, but it would be a mistake not to realize or take seriously the idea that a version of belonging (distorted as it is) is at play when the "crime of crimes" is committed. It is far too easy to attribute genocide to fanatics and psychopaths, but that will neither help us to fully understand the nature of the impulse to destroy nor enable us to respond to it more fully and successfully.

In the last paragraph, I used the phrase "imagining communities" so let me briefly note here what I mean by this notion. The idea of "imagined communities" is that of Benedict Anderson's who coined the phrase to describe the nation. ${ }^{44}$ Anderson did not use the phrase to suggest that the communities so imagined (including the nation) are false or fabricated. Indeed, Anderson observes that "all communities larger than primordial villages of face-to-face contact (and perhaps even these) are imagined." 45 Why does he think they are imagined? They are imagined because members of those communities "will never know their fellow-members, meet them, or even hear of them, yet in the minds of each lives the image of their communion." 46 Anderson's claim of imagined communities also suggests that "belonging" is not something that simply or ontologically happens, but something that is achieved. 47

For Anderson, "communities are to be distinguished, not by their falsity/genuineness, but by the style in which they are imagined." 48 As I shall show in the next section, genocide is one way (albeit an abhorrent way) of imagining a community and belonging. In the sections that follow I shall also argue that the international community's response to the threats or acts of genocide (either through universal jurisdiction or R2P) is also a way of imagining a community - a very different community, a counter community to the supposed pure community of which the genocidaire fantasizes. R2P and universal jurisdiction affirm and embrace hybridity.

44 Benedict Anderson, IMAgined COMMUnities: ReFlection ON THE ORIGIN AND SPREAD OF NATIONALISM (2d ed. 1991).

45 Id. at 6.

$46 \mathrm{Id}$.

47 Vikki Bell, Performative and Belonging: An Introduction, 16 THEORY, CULTURE AND SOC'Y. 1, 3 (1999) ("It is worth reiterating that the collection begins from a position which insists that one does not simply or ontologically "belong" to the world or to any group within it. Belonging is an achievement at several levels of abstraction.").

48 ANDERSON, supra note 44 , at 6. 


\section{GENOCIDE AND THE PROCESS OF IMAGINING COMMUNITIES}

\subsection{Communities and Positive Sentiments}

As noted earlier, the first challenge to the assertion that genocide is an exercise in community building is premised on the proposition that community is a notion constituted only by positive sentiments. ${ }^{49}$ This critique is easy to counter. There is nothing that conceptually compels us to think of communities as organized only by positive sentiments or commitments. After all, the word "community" is derived from the Latin communicare, which simply means "to share, to join and to unite." 50 To be sure, positive sentiments will always form part of the motivation for engaging in an exercise in community building, but one can cite many communities whose primary organizing principles are less than admirable or virtuous. Indeed, this was Adolf Hitler's point when he opined that "common criminality" 51 is one way to build communities. There are two ways of looking at the role negative sentiments play in the construction or imagining of communities. The first is in circumstances where the predominant impulse that gathers members into a unit is such a sentiment. A good example is a criminal gang or "common criminality," as Hitler referred to it. I say the "predominant sentiment" because even under these circumstances there is often a sense of belonging at play where members use these common criminal enterprises as a way of forging solidarity that they might have thought was unavailable to them elsewhere. The second way to look at the

49 It is important to note here that even those who believe that communities are on the whole motivated and constituted by positive sentiments do not deny that some communities fail while others succeed. So, the argument against communities as positive projects is not an argument that some communities in fact fail to achieve the sentiments that brought members together, but rather the argument is that members that attempt to constitute a community may also be motivated by less than admirable sentiments and they may in fact be successful communities in their own terms.

50 Peter Gould, Dynamics Structures of Geographic Space, in COLLAPSING SPACE AND TIME: GEOGRAPHIC ASPECTS OF COMMUNICATIONS AND INFORMATION 3 (1991) (describing the roots of the word "communication").

51 Norman H. Baynes, 1 The Speeches of Adolf Hitler, April 1922-August 193975 (1942) ("There are two things which can unite men: common ideals and common criminality"), cited in THOMAS KÜHNE, BELONGING AND GENOCIDE: HITLER'S COMMUNITY, 1918-1945 91 (2010). An example of a community built on common criminality is a criminal gang. 
issue of negative sentiments is to argue that every community, even when primarily motivated by positive sentiments, is secondarily about defining itself against the Other, other communities and other groups. Identities, whether individual or communal, are always defined in relation to or in contrast with others - other individuals and other communities. ${ }^{52}$ In that process there will necessarily be negative sentiments that will play a role to one degree or another. In Rwanda, being a Hutu was partly defined as "not being a Tutsi" 53 and being a Hindu in India is in part understood as "not being a Muslim."

To summarize, whether negative sentiments play a primary or secondary role, such sentiments play a part in the constitution or imagining of communities. The notion that communities can be organized only around positive sentiments is neither logically nor empirically defensible.

\subsection{Communities and Consequences}

The second challenge is a more serious one. Genocide, the argument goes, cannot be an exercise in community building, for genocidal events take place because there are already communities which are at odds with (or hate) one another. According to this view, genocide is a consequence of, not an exercise in, community building.

There is some truth to this observation. Often, both the victims and the victimizers have organized themselves into distinct communities prior to the genocidal encounter. That is, there is already some sense of group membership and belonging when genocides take place. There was a Jewish community in Germany and Eastern Europe prior to the Holocaust. There was a Tutsi community prior to the Rwanda genocide, and an Armenian community preceding the

52 See Addis, Individualism, Communitarianism, and the Rights of Ethnic Minorities, 67 Notre DAME L. REV. 1219, 1226 (1992) (explaining that group identities are established in relation to others and other groups); see also WILLIAM E. CONNOLLY, THE ETHOS OF PLURALIZATION 163 (1996) (arguing that boundaries make individual and collective identities possible, but they also "close off possibilities of being that might otherwise flourish." Closing off possibilities does not simply restrict freedom to establish other forms of communities, but at times lead to the destruction of existing communities as well. Therefore, boundaries play a paradoxical role: they affirm and restrict or destroy freedom.).

53 See GoureViTCH, supra note 10, at 50 (explaining that "[A] Hutu was what a Tutsi was not, and vice versa."). 
Armenian genocide (the first known genocide of the 20 th century)..$^{54}$ The existence of the group may be a matter of self-perception as well as perception by others. That is, members see themselves as a unit and others also see them as a unit. At times, the solidity of the group might be more a construction put by others than members themselves. Thus, for example, many Hutus saw Tutsis as alien in the literal sense-as invaders and conquerors of Hutu land-even though there was no historical evidence for such a claim. ${ }^{55}$ For the genocidaire, his perception of the existence of the group and his judgment of the threat that the group poses to the community to which he belongs are sufficient bases for genocidal intent or act. It may be immaterial whether the members of the victim group saw themselves as a group or whether they genuinely pose a threat to the genocidaire group.

54 The Armenian genocide began on April 24, 1915 and lasted until 1923. See Rouben P. Adalian, The Armenian Genocide, in CENTURIES OF GENOCIDE: ESSAYS AND EYEWITNESS ACCOUNTS 117 (Samuel Totten and William S. Parsons eds., 4th ed., 2013) (providing the dates and details of the Armenian genocide). There is no consensus on the exact number of victims of the Armenian genocide. The estimates range from 600,000 to 1.5 million. See KIERNAN, supra note 23, at 415 (providing victim estimates). Although Turkey had generally been successful in making sure the world did not recognize the massacre of Armenians by Ottoman Turks during the WWI era as a genocide, recent statements, including one by Pope Francis, seem to suggest that the tide is turning. See Jim Yardley and Sebnem Arsu, Pope Calls Killing of Armenians "Genocide," Provoking Turkish Anger, N.Y. TIMES, April 12, 2015, https://www.nytimes.com/2015/04/13/world/europe/pope-calls-killings-ofarmenians-genocide-provoking-turkish-anger.html] [https://perma.cc/7M3Z3RK6] (Last visiting Mar. 6, 2017) ("Pope Francis on Sunday described the World War I-era slaughter of Armenians by the Ottoman Turks as the first genocide of the 20th century, igniting a diplomatic confrontation with Turkey, which quickly summoned the Vatican's ambassador to condemn the pontiff's remarks and recalled its own ambassador to the Holy See."). The German Parliament more recently recognized the Armenian genocide, not unexpectedly leading to protest from Turkey. Alison Smale \& Melissa Eddy, German Parliament Recognizes Armenian Genocide, Angering Turkey, N.Y. TIMES, June 2, 2016, https://www.nytimes.com/2016/06/03/world/europe/armenian-genocide-germany-turkey.html [perma.cc/QR3Q-CCWM]. Turkey continues to deny that the killings during the war can be characterized as genocide. Tim Arango, A Century After a Genocide, Turkey's Denial Only Deepens, N.Y. TIMES, April 17, 2015, at A1 ("It also remains that conflict's most bitterly contested legacy, having been met by the Turkish authorities with 100 years of silence and denial.").

55 See GOUREVITCH, supra note 10, at 53 (describing the mindset of the individuals within the conflict); see also ALISON DES FORGES, LEAVE NONE TO TELL THE STORY: GENOCIDE IN RWANDA 79-81 (1999) (describing the false portrayal of Tutsis that led to massacres); and KIERNAN, supra note 23, at 555 (pointing out historical developments that influenced the perceptions of Tutsis by Hutus); but see generally ADAM JONES, GENOCIDE: A COMPREHENSIVE INTRODUCTION (2006). 
However the group is constructed, critics of the idea of genocide as an exercise in community building ask: how could genocide be understood other than an act that follows and is premised on the existence of communities at odds with one another?

There are two responses to this claim. The first is conceptual, the second is empirical. First, to view communities and their actions only in terms of cause and consequence is to have an unsatisfactory view of communities. Only if one views communities as solid and stable would one believe that the acts of communities do not have an impact on the nature and character of those very communities. The fact of the matter is that every major encounter among communities reshapes or recasts those communities. The more major the encounter or event, the more likely the effect on the nature and character of the community will be greater and more pronounced. 56 Genocide is one of those events. What genocide does is of course take the notion of the purity of communities to another level. It is not just about forcing the Other from a particular territory, but rather eliminating it altogether. ${ }^{57}$ This affects the nature of the community in one of two ways. The first and most obvious way is the sense that genocide is intended to reestablish the perpetrator community as a pure community both in the territorial and existential sense. Indeed, the process is sometimes carried out in a context where members of the victim community are not even described as members of the human species. During the Rwanda genocide, for example, Hutus referred to the Tutsis they were slaying as "cockroaches." 58 Armenians were termed "tubercular microbes" during

56 See Addis, Individualism, Communitarianism, and the Rights of Ethnic Minorities, supra note 52, at 1226 . See also Adeno Addis, Community and Jurisdictional Authority, in BEYOND EXTRATERRITORIALITY: TRANSNATIONAL LEGAL AUTHORITY IN AN AGE OF GLOBALIZATION 32 (Gunther Handl, Joachim Zekoll and Peer Zumbansen eds. 2012) (arguing that communities "change in the process of interacting with other communities, in the same way that individual identities change in the course of individuals interacting with other individuals.")

57 The tragic consequence of thinking in terms of pure communities is, of course, not limited to ethnic or religious conflicts. To some extent, what was tragic about communism of the twentieth century was precisely the pseudo-revolutionary thinking that the communist utopia was a purified form of community where certain individuals do not have a place.

58 A local Rwandan radio station apparently incited the Hutus to violence: "You have to kill the Tutsis, they're cockroaches." Rwanda Genocide: 100 Days of Slaughter, BBC NEws, Apr. 7, 2014, http://www.bbc.com/news/world-africa26875506 [https://perma.cc/LJA5-WRB8]. See GOUREVITCH, supra note 10, at 3 ("'You cockroaches must know that you are made of flesh,' a broadcaster at Radio Mille Collines proclaimed, 'We won't let you kill. We will kill you.'”). This, of 
the Armenian genocide.59 Hitler spoke of the "Jewish virus," 60 and the extermination of Australian Aborigines was compared to the "drainage of marshes" and "the disappearance of wild animals." 61 Such references allow the members of the perpetrator community to empty themselves of any sense of empathy to the extent that humans might have been owed some empathy. Animal imagery allows perpetrators to maintain "psychological distance from their victims and from the nature of their tasks as killers." 62

If the victim community survives, the relationship between those communities (perpetrators and victims) is obviously drastically changed. The way those communities view each other will be entirely and radically different - not only in terms of how each community sees the other, but also how each community sees itself as

course, was not the first time the term "cockroach" had been used by Hutus to describe Tutsis. It had apparently been used for a long time. See Prosecutor v. Akayesu, Case No. ICTR 96-4-T, Judgment, I 90 (Sept. 2, 1998) (when a conflict started between Hutus and Tutsis almost immediately after independence, Hutus used the word Inyenzi, meaning cockroach, to refer to Tutsi exiles who made incursions into Rwanda). Other references and imagery were also employed in the purification process, such as "bush clearing" and "pulling out the roots of the bad weeds." See GÉRARd PRUNIER, THE RWANDA CRISIS: HistORY OF A GENOCIDE 142 (1997); see also KIERNAN, supra note 23, at 558-559 (describing the use of "cockroach" to label Tutsis).

59 Peter Bakalian, The Armenian Genocide and the Modern Age, 20 THE SYDNEY PAPERS, 144, 150 (2008). Apparently, a local politician then rhetorically asked, "isn't it the duty of a doctor to destroy these microbes?" $I d$.

60 HitleR's TABle TALK 1941-1944: SeCRET CONVERSATIONS 332 (H.R. TrevorRoper ed., 2d ed. 2000); see also ZYGMUNT BAUMAN, MODERNITY AND THE HOLOCAUST 71 (1989) (discussing the "Jewish virus"). Hitler then remarked that "by eliminating the pest," he would do "humanity a service." See KIERNAN, supra note 23, at 440 ("Jews were 'vermin' and 'lice.'”).

61 D.J. Mulvaney, The Australian Aborigines, 1606-1929, 8 HIST. STUD. 135, 145 (1958) (citing JR MCCUllough, A Dictionary GEOGRAPHICAL, STATISTICAL, AND HISTORICAL § 2:230 (London 1847). For a short account of the genocide in Australia with some eyewitness accounts, see generally Tatz, supra note 35, at 55 .

62 Jim Fussell, Indangamuntu 1994: Ten Years Ago in Rwanda This Identity Card Cost a Woman Her Life, PREVENT GENOCIDE INTERNATIONAL, http:/ / www.preventgenocide.org/edu/pastgenocides/rwanda/indangamuntu.htm

[https://perma.cc/5KBX-8L47]. Bradley Campbell gives a more comprehensive account of "distance" that he claims needs to exist for genocide to occur. There must be "cultural," "relational," and "functional" distance between the relevant communities for there to be threat of genocide. Campbell, supra note 34, at 161-165. By cultural distance, Campbell meant to refer to "differences in the content of the culture." Id. at 161. "Relational distance" refers "to the extent to which people participate in each other's lives." Id. at 162. And "functional distance" refers to "the extent to which individuals and groups cooperate with one another economically, politically, militarily or otherwise.'" Id. at 164. (citation omitted). 
well. And under certain circumstances, the genocide (the event) itself, including its memory and commemoration, might become a sufficient basis of communion for some members, even if those members are no longer adherents to other aspects or rituals of the culture. ${ }^{63}$

The second response to the challenge is based on an empirical claim that participating in certain acts leads to solidarity and community. This was Hitler's point when he opined that common criminality in fact leads to a sense of community and solidarity. ${ }^{64}$ This is clearly the case in relation to criminal gangs. To some extent that is what happens to fighting units in an army as well. Another example is when a young Muslim man or woman in the U.S., 65 U.K., or France, often a child of immigrants, is recruited by the Islamic State in Iraq and Syria (ISIS) or al Qaeda operatives to join them in building a community. The promise is that he or she will be a central player, not an outsider. It is not so much the territorial space that attracts this young man or woman, but rather the idea of a community, and of belonging to and building that community, in the process of waging war against the Other. ${ }^{66}$ That community is going to

63 See Joane Nagel, Constructing Ethnicity: Creating and Recreating Ethnic Identity and Culture, 41 SOC. PROBS. 135, 154 (1994) (explaining the influence of memory). But, of course, the genocide may unite otherwise diverse members of perpetrators as well. The New York Times reporting on the 100th anniversary of the Armenian genocide made the following observation about Turkey's response of denial: "In a country defined by its divisions between the secular and the religious, rich and poor, liberals and conservative, the legacy of the Armenian genocide is a unifying issue for Turks." Tim Arango, A Century After a Genocide, Turkey's Denial Only Deepens, N.Y. TIMES, April 17, 2015, at A1, A8.

64 See KÜHNE, supra note 14, at 164 ("The conclusion is inescapable: the Nazi regime not only propagated a racially defined national community, the Volksgemeinschaft, but established it as a political, social, and psychological reality, not so much by providing Germans with economic benefits or by resolving their class conflicts but by making Germans complicit in mass crime.").

65 Not long ago, two American teenage girls (of Sudanese and Somali heritage) from Denver, Colorado were apprehended in Germany while en route to Syria apparently to join ISIS. Mike Levine, Pierre Thomas and Clayton Sandell, Three American Girls En Route to Syria Planned to Join Militant Groups, Officials Say, ABC NEWS, Oct. 21, 2004, available at http://abcnews.go.com/International/american-girlsen-route-syria-tracked-fbi/story?id=26353762 [https:/ / perma.cc/6U57-CTTN].

66 See Danica Kirka, Study Says Girls Seek 'Sisterhood' - Not Just Jihadi Marriage in Islamic State, WASHINGTON POST (May 28, 2015), http://www.washingtontimes.com/news/2015/may/28/study-says-girls-seek-sisterhood-_-not-just-marria/ [https://perma.cc/UC86-NB5H] ("The notion that young women are traveling to Syria solely to become 'jihadi brides' is simplistic and hinders efforts to prevent other girls from being radicalized, new research suggests. Young women are joining the Islamic State group for many reasons, including anger over the 
be built by destroying those who are seen to be the outsiders, the enemy, those who form the outer boundary of the community to which he/she seeks to belong and those who, they are told, will eliminate them if they do not help eliminate them first. 67 The community is "a community of fate and struggle" and it is based on the idea of the purity of communities. ${ }^{68}$ One of Jean-Paul Sartre's compelling insights in Anti-Semite and Jew is that the anti-Semite (and one could add any genocidaire) is driven by the extraordinarily fanciful belief that harmony will be re-established once the evil Other is eliminated in the same way that a healthy body will be restored once a virus is eliminated. ${ }^{69}$

The Rwanda genocide offers another and, for our purposes, a more relevant example. The roving bands of Hutus who inflicted unimaginable terror for about 100 days were referred to as interahamwe, "those who attack together."70 In the process of killing, maiming, raping, torturing and disfiguring, the bands of Hutus formed what was essentially not very different from a criminal band. The interahamawe did not just attempt to purify the community that existed, but to solidify it as well. Purity is a matter of the relationship between the community and the Other (i.e. the other community); solidity is a question of how strong the bonds are among members of a particular community. One could view the first as a question of dimension and the second as a question of

perceived persecution of Muslims and the wish to belong to a sisterhood with similar beliefs, according to a report released Thursday by the Institute for Strategic Dialogue and the International Center for the Study of Radicalization at King's College London.").

67 In a recent blog, an anthropologist who has "spent much time observing, interviewing and carrying out systematic studies among people on six continents who are drawn to violent action for a group and its cause" in Iraq "among young men who had killed for ISIS" and potential recruits in Paris and barrios of Barcelona, made the following observation: these young men knew very little about Islam (the Quran and Hadith) or the early caliphates "but had learned of Islam from $\mathrm{Al}$ Qaeda and ISIS propaganda, teaching that Muslims like them were targeted for elimination unless they first eliminated the impure." Scott Atran, Here's What Social Science Says About Countering Violent Extremism, HuffingTON POST (Apr. 25, 2015), http:// www.huffingtonpost.com/scott-atran/violent-extremism-social-science_b_7142604.html [https://perma.cc/4R49-L77Q] (Last visited Mar. 6, 2017).

68 The irony of imagining purity in a world of hybridity is frighteningly dangerous. And that, of course, is precisely the problem.

69 Jean-Paul Sartre, Anti Semite And Jew (1948).

70 Gourevitch, supra note 10 , at 92. 
depth. ${ }^{71}$ Put simply, the community is imagined both in terms of its relationship with the other community and the relationship amongst its members. The genocide of the interahamwe cannot be understood as collective madness or mob mania, nor a crime of passion motivated by deep hatred, as some tend to see it. Rather, it was a well-organized and efficiently planned exercise of community building with "great ambition." 72 Indeed, that was the conclusion that Thomas Kühne reached in his fascinating study of genocide and belonging in relation to Hitler's Germany. ${ }^{73}$ Sociologists have shown that collective violence such as genocide - the process of destroying the symbols, bonds, and identities of the victim groups binds the perpetrators to a collectivity and solidifies their identity. ${ }^{74}$

Interestingly, it is not just in terms of the process of killing and maiming that the Hutu bands saw themselves as a community of

71 For an interesting, but slightly different, account of the dimensions and depths of identities, see CONNOLLY, supra note 52, at 46 (explaining how responsibility influences cultural identities).

72 GOUREVITCH, supra note 10, at 17; see also Fussell, supra note 62 ("The Rwandan genocide was systematic and organized and not an indiscriminate or wanton slaughter as it was sometimes later portrayed."). For a general and an extended assessment of why it is erroneous to think of collective violence, such as riots, as collective madness or mania, see generally DONALD L. HOROWITZ, THE DEADLY ETHNIC RIOT (2001) (arguing that rioters are not irrational; they choose their targets selectively and they employ both emotion and reason to prosecute their plan).

73 See KÜHNE, supra note 14, at 164 ("The conclusion is inescapable: the Nazi regime not only propagated a racially defined national community, the Volksgemeinschaft, but established it as a political, social, and psychological reality, not so much by providing Germans with economic benefits or by resolving their class conflicts but by making Germans complicit in mass crime."); see also Cesarani, supra note 14, at 162 ("'The nation that slays together, stays together.' This, in a nutshell, is the thesis of Thomas Kühne's provocative essay on German society under the Nazis."); see also Benjamin Lieberman, From Definition to Process: The Effects and Roots of Genocide, in NEW DiRECTIONS IN GENOCIDE RESEARCH 3, 9 (Adam Hones ed. 2012) ("In the early stages of the development of an imagined community such as a nation, genocide is also a method to forge or build that community or nation. Turkey provides an important example. The Armenian Genocide and the simultaneous destruction of Assyrian Christians within core areas of the shell of the Ottoman Empire sped the formation of a Turkish nation within what would soon become a Turkish nation-state.").

74 See, e.g., Harold Garfinkel, Conditions of Successful Degradation Ceremonies, 61 AM. J. SOC. 421 (1956) (describing moral indignation as fueling the destruction process); see also INGA CLENDINNEN, READING THE HolOCAUST 138-55 (1999) (relating stories of Nazi collective violence during WWII); and KÜHNE, supra note 14, at 78 (" [W]e see the triumphant group of perpetrators [of genocide] enjoying themselves committing or watching cruelty."). The idea of collective violence being a means of building a community should not be that unfamiliar or strange. In many circumstances the nation-state, that central institution of our current world, was born of collective violence. 
actors; they also saw themselves as a community of future victims who would be subject to Tutsi revenge if the job were not completed. A similar sentiment was expressed during the genocide in WWII. Herman Göring, "chief of Luftwaffe and designated successor of Hitler," is quoted as having expressed the following in 1942: "If we lose the war, you will be annihilated .... The Jew is behind everything, and it is he who has declared a fight to the death, and to ruin against us." Göring then went on to say that, "The Jew with his Old Testament hatred is what we are to expect if the Jew is enabled to take revenge on us." 75 The group that united itself as victimizer now wants to sustain that unity by turning members into potential victims. Both in the Rwanda and Nazi Germany cases, the community of purifiers was reinforced by the community of potential victims.

To summarize, the genocidaire simultaneously destroys a community and attempts to chase the fanciful idea of his pure community. Genocide is an activity that brings people together as killers and as victim (or potential victim) groups. Community and belonging are the very foundations of genocide. But the notions of community and belonging are based on the seemingly contradictory dualistic self-view of the perpetrators of genocide: superiority and vulnerability. ${ }^{76}$ If we forget to understand this, we will have undermined our chances of responding to genocide and threats of genocide more effectively.

\section{GENOCIDE, LAW AND BELONGING}

Quite often, when we think about mass crimes such as genocide, we think of the space beyond law. These crimes are thought to occur in a space and at a time when law is not functioning or is not in control. On the surface, this way of thinking makes perfect sense. It is often a given that mass murder, often involving groups as victims and as perpetrators, is non-law or beyond law. However, this intuitive understanding of the relationship between law and mass crimes is misleading. It masks the disturbing truth that mass crimes are often preceded by (and their occurrence prepared for) by all sorts of law. People don't simply wake up one day and commit genocide.

75 KÜHNE, supra note 14 , at 131.

76 See Norman Cigar, GenOCide in Bosnia: The Policy of ETHNic Cleansing 78 (1985) (The "dualistic self-view of superiority and accompanying vulnerability bordering on paranoia can be a particularly explosive mix."). 
They start setting themselves (or are set) apart from others, seeing other groups or communities as evil, as a mortal threat, or as simply impure.

This attitude or disposition is often accomplished through law. At times, there is formal law 77 that marks or constructs the particular group as a distinct category and is subsequently used as the basis on which the group is physically eliminated or socially debased. Thus, for example, before Auschwitz there was law. ${ }^{78}$ There was a legally constituted state and a people which defined itself, "legally, almost purely in terms of its Other, The Jew." 79 Jews were written into law as the dangerous Other. ${ }^{80}$

77 By "formal law," I refer to law emanating from the State through the normal processes that law is adopted in the particular state.

78 For a detailed and interesting study of the role of law in the period before and after Auschwitz, see generally DAVID FRASER, LAW AFTER AUSCHWITZ: TOWARD A JURISPRUDENCE OF THE HOLOCAUST (2005). The following are some of the laws: Law for the Restoration of the Professional Civil Service, art. 3 ("Civil servants who are not of Aryan descent are to be retired; if they are honorary officials, they are to be dismissed from their official status."); the regulation passed on April 11, 1933 pursuant to the Civil Service Law made it clear what the phrase "not of Aryan decent" meant when it stated: "A person is to be considered non-Aryan if he is descended from non-Aryan, and especially from Jewish parents or grandparents;" the Law for the Protection of German Blood and Honor, passed on November 14, 1953, declared that "Marriage between Jews and citizens of German or kindred blood are forbidden .... . Sexual relations outside marriage between Jews and nationals of German blood or kindred blood are forbidden." And the Hereditary Farm Law stipulated that "only men of German or related blood can become farmers (Bauern)."

79 FrASER, supra note 78, at 15; see also MichaEl BURLEIGH AND WOLFGANG WipPERMANN, THE RACIAL STATE: GERMANY 1933-1945 305-306 (1991) ("The regime's 'national community' was based upon the exclusion and extermination of all those deemed to be 'alien', 'hereditary ill', or 'asocial'. These 'elements' were subject to constant and escalating forms of selection. The 'national community' itself was categorized in accordance with racial criteria."); For a fascinating account of how the Nuremberg laws, especially the second and third Nuremberg laws, which defined the Jew as a threat to both German blood and honor, developed and how American racist laws were Hitler's model, see JAMES Q. WHITMAN, HITLER'S AMERICAN MODEL: THE UNITED STATES AND THE MAKING OF NAZI RACE LAW (2017). ("In the early 1930s, Nazi lawyers were engaged in creating a race law founded on anti-miscegenation law and race-based immigration, naturalization, and secondclass citizenship law. They went looking for foreign models, and found them - in the United States of America," Id, at 16); see also Campbell, supra note 34, at 155 (describing genocide as a form of social control to address grievances against targeted ethnic groups).

80 FRASER, supra note 78, at 6 ("Nazi law recreated the Jew as a separate and distinct legal category in order then to destroy the category itself."); see also id. at 31 ("'The Jew' is the unwritten and necessary Other of the Volk."); see also KÜHNE, supra note 14, at 164 ("The conclusion is inescapable: the Nazi regime not only propa- 
In Rwanda, too, there was a great deal of law that preceded (and prepared the ground for) the genocide. There was, for, example, a requirement that one register and carry identity cards identifying him/her as Tutsi or Hutu. ${ }^{81}$ A Hutu then imagined himself as "what a Tutsi was not, and vice versa." 82 Those identity cards "served as death tickets for Tutsi during the genocide." 83 In relation to the Balkan conflict, the International Court of Justice found that there were circumstances where individuals were forced "to wear signs of membership of a group," the purpose of which was "to stigmatize the group's members." 84 Often, such marking is not just a matter of stigmatizing but it also makes it easier to attack or eliminate members of the group and it may certainly signify "the intent to destroy the group[.]" 85 In other circumstances, formal law was employed by state authorities to lay the groundwork for the genocidal acts that followed. 86

gated a racially defined national community, the Volksgemeinschaft, but established it as a political, social, and psychological reality, not so much by providing Germans with economic benefits or by resolving their class conflicts but by making Germans complicit in mass crime.").

81 Group classification and ID cards were introduced by the Belgian colonial government in 1933. Gourevitch, supra note 37, at 14 ("[I]n 1933-34, the Belgians conducted a census in order to issue identity cards, which labelled every Rwandan as either Hutu (eighty-five per cent) or Tutsi (fourteen per cent) or Twa (one per cent). The identity cards made it virtually impossible for Hutus to become Tutsi, and allowed the Belgians to perfect the administration of an apartheid system that perpetuated the myth of Tutsi superiority.").

82 GOUREVITCH, supra note 10 , at 50.

83 Gourevitch, supra note 37, at 22. An ID card with the designation of "Tutsi" meant that the person at a roadblock would almost certainly face death. See Prosecutor v. Akayesu, supra note 58, at 123 (describing the roadblocks); see also Alison Des Forges, Leave None to Tell the Stories, Human Rights WATCH 147 n.60 (1999) (pointing to attempts to remove ethnic categories from identity papers) (citation omitted); Jean de la Croix Tabaro, The Passport to Death: Story of Rwanda's Notorious ID, KT PRESS (July 13, 2015), http://ktpress.rw/2015/07/the-passport-to-deathstory-of-rwandas-notorious-id/ [https://perma.cc/5UX3-URGP] (Last visited Mar. 6, 2017); Fussell, supra note 62 ("Along with the prior training of militias, stockpiling of weapons, direction of the massacres by hate radio, the prior existence of ethnic ID cards was one of the most important factors facilitating the speed and magnitude of the 100 days of mass killings in Rwanda." Just above this statement Fussell displays the ID card of the woman who lost her life.).

84 Application of Convention on Genocide, supra note 35 at 382.

85 Id. at 417.

86 Cambodia under the Khmer Rouge and the Armenians in the Ottoman Empire are good examples. For a general account of the role of law in the perpetration of genocide, see generally JENNIFER BALINT, GENOCIDE, STATE CRIME AND THE LAW: IN THE NAME OF THE STATE (2012) (focusing on what she considers to be seven instances 
In terms of law facilitating genocides and ethnic cleansing, earlier societies were no different. ${ }^{87}$ Thus, in relation to the early history of the United States and its dealings with Native Americans, law was used as a source of ethnic cleansing. In his inaugural address as president of the United States in 1828, Andrew Jackson called for a federal Indian Removal Act through which the region (such as the state of Georgia) was to be "cleansed" of Indians. Congress passed the removal bill, which was then signed into law by Jackson. As Kiernan notes, although under the law removal was going to be voluntary, "most Indians would leave only under threat and harassment." 88 Perhaps not surprisingly, speaking in 1942 about the Germanization of Poland, Hitler cited United States' action in relation to Native Americans as a parallel: "The struggle we are waging there (i.e. Poland) against the Partisans resembles very much the struggle in North America against the Red Indians. Victory will go to the strong." 89

At other times, the law might not be formal or state-generated (an expression of the will of the sovereign ${ }^{90}$ ), but instead what Michael Reisman refers to as "microlaw."91 The idea that lawmaking

of genocide, Balint shows how law is a companion/a facilitator of genocidal community building).

87 See generally KIERNAN, supra note 23 (providing a global history of genocide and extermination from ancient times).

88 Id. at 332.

89 Hitler, August 8, 1942, in Hitler's TABlE TALK, 1941-42: His Private CONVERSATIONS supra note 60 at 284. See also JAMES Q. WHITMAN, HITLER'S AMERICAN Model: The United STATES AND THE MAKING OF NAZI RACE LAW 47 (2017) who quotes Hitler as having expressed his admiration of America for the westward expansion of the "Nordic" stock and the slaughter of Native Americans. America, Hitler notes, had "gunned down the millions of Redskins to a few hundred thousand" which he thought Europeans would do well to emulate.

90 Here "both the ultimate origin of law and the ultimate sanction of law" are seen to inhere in "the will of the state." HAROLD J. BERMAN, THE NATURE AND FUNCTION OF LAW 21 (1958); see also ROBERTO MANGABEIRA UNGER, THE CRITICAL Legal Studies Movement: ANOTHer Time, A GreAter TASK 56 (2015) (exploring what he calls the "universal history" of legal thought (which he critiques), Unger identifies three elements in that universal history one of which is "the view of law as the will of the state or of the sovereign.").

91 Michael Resiman, LAW In BRIEF ENCOUNTERs 2 (1999) ("The law of the state may be important, but law, real law, is found in all human relations, from the simplest, briefest encounter between two people to the most inclusive and permanent type of interaction. Law is a property of interaction. Real law is generated, reinforced, changed, and terminated continually in the course of almost all of human activity. This law, which I refer to as "microlaw," also manifests a constitutional dimension or, to put it more dynamically, a constitutive process: part of every de- 
is not exhausted by the action of state-centric institutions or processes was powerfully made by Robert Cover in a series of articles. ${ }^{92}$ For Cover, the state-centric vision of law is incomplete and the legal processes and legal actors encompass a normative universe held together by the force of interpretive commitments of communities, some of whom are small and private while others are large and public. ${ }^{93}$ According to Cover, lawmaking therefore occurs in various communities with different sizes and organizational characters. ${ }^{94}$ I

cision is concerned, not with the immediate decision, but with the structure of decision-making itself."). The idea of labeling "microlaw" (essentially custom, usage and ordered social relations) as "real law" is of course controversial. Critics argue that this is too inclusive a view of law which threatens to make law become everything and hence nothing. Positivists, who essentially limit the label to rules and regulations that have their origin with the state, and natural law theorists who reserve the label for attempts to explicate law out of rightness or right reasons, clearly do not consider custom or usage to be law on their own rights. I do not wish to enter that debate here. For my purposes, it is sufficient that some customs and usages have the functional equivalent of law and there is in fact a well-respected school of jurisprudence - historical-sociological jurisprudence - that embraces "microlaw." See EugEnE EHrLICH, THE FundAMENTAL PRINCIPLES OF THE SOCIOLOGY OF LAW 497 (1975) ("The living law is not the part of the content of the document that the courts recognize as binding . . . but only that part which the parties actually observe in life." Ehrlich goes on to make the following observation at another point in the book: "It is not an essential element of the concept of law that it be created by the State nor that it constitute the basis for the decision of courts or other tribunals, nor that it be the basis of a legal compulsion consequent upon such a decision. A fourth element remains, and that will have to be the point of departure, i.e. the law is an ordering." ). Id. at 24 . For the criticism that this highly inclusive notion of law threatens to undermine the very idea of law, see FELIX COHEN, THE LEGAL CONSCIENCE 187 (1960) (arguing that Ehrlich is confused with respect to definitions dealing with notion of law); see generally PAUL SCHIFF BERMAN, GLOBAL LEGAL PLURALISM: A JURISPRUDENCE OF LAW BEYOND BORDERS (2012) (providing an interesting account of the various circumstances within which law emerges and the multiple venues out of which it springs); see also LEOPOLD POSPISIL, ANTHROPOLOGY OF LAW: A COMPARATIVE THEORY 125 (1971) ("Society, be it a tribe or a 'modern' nation, is not an undifferentiated amalgam of people. It is rather a patterned mosaic of subgroups that belong to certain, usually well-defined (or definable) types with different memberships, composition, and degree of inclusiveness. Every such subgroup owes its existence in a large degree to a legal system that is its own and that regulates the behavior of its members.").

92 See generally Robert M. Cover, The Supreme Court, 1982 Term, Foreword: Nomos and Narrative, 97 HARV. L. REV. 4 (1983); Robert Cover, Violence and the Word, 95 YALE L.J. 1601 (1986); Robert Cover, The Use of Jurisdictional Redundancy: Interest, Ideology, and Innovation, 22 WM. \& MARY L. REV. 639 (1981); Robert Cover, Obligation: A Jewish Jurisprudence of the Social Order, 5 J. L. \& RELIG. 65 (1987) (stating that "Judaism is, itself, a legal culture of great antiquity .... [I]t can lay as much claim as any of the other great legal cultures to have an integrity to its basic categories.").

93 See generally Cover, The Supreme Court, supra note 92.

94 See Cover, The Use of Jurisdictional Redundancy, supra note 92, at 682 (describing how systems inevitably includes tensions and conflicts of social order); see also 
shall refer to law outside the state as "regulatory cultural norm." 95 Whether one refers to it as microlaw, non-state law, informal law, or regulatory cultural norm, law here is a property of tradition and culture and, as in formal law, it structures the decision-making process within the particular community while simultaneously imagining the community itself. In relation to informal law's role in genocide, Neha Jain was surely right when she observed that the "perpetrator of an international crime (in our case, genocide) acts within a moral and cultural universe where his actions correspond to the values of the group to which he belongs." 96 The normative universe within which the genocidaire acts both imagines the "pure" community, which the genocidaire seeks to establish, and also lays the groundwork for establishing it. That is not to say that there are no dissensions within the culture, both about the unfavorable perception of the targeted groups and of the idea of a pure community itself. Rather, it is simply to suggest that the genocidaire acts within a widespread cultural belief or normative universe that views the targeted group as the evil Other who must be removed from the community.

Hence, in Rwanda, even without the formal identity cards, people had developed customs or micro-law through which they marked each other as an indication of what they were not and would not want to be. Quite often those norms created a distinct group, where the existence of such a group prior to the law had been ambiguous. In relation to Rwanda, for example, the evidence shows

Cover, The Supreme Court, supra note 92, at 43 (pointing out how communities often generate norms in different ways with competing "rules of recognition").

95 I must emphasize here what I noted earlier: there is intense debate within the legal community and between legal scholars and scholars in other fields (such as sociologists and anthropologists) as to whether there is such a thing as non-state law. For many legal scholars, law is a property of the state and the regulatory norms invoked and enforced by non-state actors do not deserve to have the label of "law" attached to them. For legal pluralists (whether legal scholars or scholars in other fields), law as a regulatory norm is present in various arenas (cultural and religious groups, indigenous peoples, non-state actors of other kinds, etc.), and to insist on state-centrism as the condition of legality is to exclude a whole lot of regulatory process in human affairs which is functionally no different from formal state generated law. See generally Marc Galanter, Justice in Many Rooms: Courts, Private Ordering, and Indigenous Law 19 J. LEGAL PLURALISM 1 (1981) (showing how the legal centrist model is deficient and how abandoning it can improve access to justice).

96 Neha Jain, Individual Responsibility for Mass Atrocity: In Search of a Concept of Perpetration, 61 AM. J. COMP. L. REV. 831, 836 (2013); see also Gourevitch, supra note 37 , at 6 ("During the genocide, the work of the killers was not regarded as a crime in Rwanda; it was effectively the law of the land, and every citizen was responsible for its administration."). 
that in the pre-colonial period, "Hutus and Tutsis spoke the same language, intermarried, followed the same religion, and shared the same social and political structure of small chiefdoms. Some live intermingled, without territorial distinction on the same hills, sharing the same social and political culture in small chiefdoms. . . Hutus could become hereditary Tutsis, and Tutsis could become hereditary Hutus." 97 In the post-colonial period, however, through formal and informal law, distinct communities were imagined. What was legally and culturally produced was then viewed as primordial. ${ }^{98}$ Indeed, one of the functions of law (whether formal or informal) is to normalize what would otherwise have looked strange or abnormal.

\section{INTERNATIONAL RESPONSE TO GENOCIDE: IMAGINING THE INTERNATIONAL COMMUNITY}

As I have argued above, as perverse as it sounds, genocide is in fact an exercise in community building. In a world of dislocation and anxiety, genocide and other mass atrocities may in the future occur more frequently than we imagine. ${ }^{99}$ Available evidence indicates that law, both in its formal and informal dimensions, is often

97 Gourevitch, supra note 37 , at 13.

98 This is the idea that genocide occurs as a result of an age-old animosity between the relevant ethnic groups who are very different from one another. Arjun Appadurai has labelled this as the "primordialist" positon. See generally ARJUN APPADURAI, MODERNITY AT LARGE: CULTURAL DIMENSION OF GLOBALIZATION (Dilip Gaonkar \& Benjamin Lee ed., 1996).

99 There are many countries that are or ought to be on genocide watch. The Secretary-General of the United Nations mentioned Syria and the Central African Republic as prime examples of a distinct possibility of genocide. See Ban Ki-moon, supra note 42 . There are many other countries which ought to be on genocide watch.. The idea of genocide watch is to ensure that relevant international or regional institutions can intervene early enough (and before the need of the use of force) to minimize the risk of a full-blown genocide. The president of Genocide Watch makes the point: "The U.N. Security Council and key governments need strong, independent Early Warning systems to predict where and when ethnic conflict and genocide are going to occur, and to present policy options on prevention and intervention." George H. Stanton, How We Can Prevent Genocide: Building an International Campaign to End Genocide, GENOCIDE WATCH (2003), available at http:/ / www.genocidewatch.org/howpreventgenocideic.html [https:// perma.cc/7ZPU-5MMH] (last visited Feb. 27, 2017). Stanton lists eight stages of genocide which he believes are predictable (and presumably therefore avoidable): classification (categorizing along certain characteristics), symbolization (imbuing those categories with symbols), dehumanization (referring to particular 
highly implicated in the creation of categories, and then in the elimination of the categories themselves. What I shall argue in this section is that if mass atrocities such as genocide are exercises in community building, then the international response to those atrocities (either to forestall or punish) is also a way (perhaps a test) to imagine the contours of the international community, a community of multiplicity in contrast and counter to the genocidaire's fantasy of a "pure" community. While genocide is about the denial of the very existence of one or another community, international response to it may be the imagining of another larger and inclusive community. On this account, international legal doctrines adopted to deal with genocide are not simply instrumental, but constitutive as well.

As I indicated earlier, I shall explore this thesis using two international legal doctrines: universal jurisdiction and the Responsibility to Protect (R2P), and show how these doctrines have been or can be used to respond to prevent or punish genocide. In the next few pages I shall briefly outline the nature of these two doctrines before I go on to explore the thesis that these doctrines are partly about a process through which the international community imagines itself. As a general comment, jurisdictional norms, perhaps more than other norms, play an important role in defining communities and belonging. Jurisdictions define what a nation, a state, a city, or a religious community is. To prescribe jurisdictional rules is to assert or to assume that a particular territorial community is a community of interest. Traditional international prescriptive and adjudicative jurisdictions define the authority of every state vis-à-vis other states. As I show in the next page, universal jurisdiction (and, to some extent, $\mathrm{R} 2 \mathrm{P}$ ) is a process through which we imagine the international community as a community of interest, a diverse albeit vulnerable community.

\subsection{Universal Jurisdiction}

Traditional international law requires that there be some connection between the jurisdiction-asserting state and the crime the state wishes to prohibit or punish. The connection might be based on the nationality of the victim or perpetrator, or on the fact that the crime

group with animal images), organization ("genocide is always organized"), polarization ("extremists drive the groups apart"), identification ("victims are identified and separated out" on the basis of the classification), extermination, and denial. Id. 
is committed on the territory of the state, or because the crime has an impact on the security interest of the state, etc. 100 Thus, prescriptive and adjudicative norms require that there be some connection between the jurisdiction-asserting state and the event which the state wishes to regulate. These norms are thought to be justified by the existence of what Ronald Dworkin, in another context, has referred to as "associative or communal obligations."101 For a legitimate adjudicative or prescriptive jurisdiction to be asserted, the regulated person or act must be connected, however thickly or thinly, to the territorial and political community we call the state. Jurisdiction here is, therefore, premised on some notion of membership to a political community. Universal jurisdiction, however, does not stem from such connection.

Universal jurisdiction is the international legal principle under which any state is permitted 102 to assert prescriptive and adjudicative jurisdiction over individuals who are alleged to have committed certain international crimes (genocide and crimes against humanity being two of them). Jurisdiction is permitted whether or not those crimes were committed within the territory of the state, and regardless of the nationality or residence of the victim or victimizer. ${ }^{103}$ That is, a state can prosecute and punish anyone who has committed cer-

100 See RESTATEMENT (THIRD), supra note 29, at $\S 402$ (listing the instances in which the state has jurisdiction to prescribe law); see also JAMES CRAWFORD, BROWNLIE'S PRINCIPLES OF PUbliC INTERNATIONAL Law 456-466 (8th ed., 2012) (providing an overview of the general bases of jurisdiction and the principles behind them).

101 RONALD DWORKIN, LAW'S EMPIRE 196 (1986). More recently, in an article he finished just before he passed away and published posthumously, Dworkin made the same point about international law. See Ronald Dworkin, A New Philosophy for International Law, 41 PHIL. PUB. AfF. 2, 11 (2013) (“We must locate the source of political obligation elsewhere [rather than "consent"]: in my view, we must locate it in the more general phenomenon of associative obligation.").

102 See RESTATEMENT (THIRD), supra note 29 , at $\S 404 \mathrm{cmt}$. A (commenting on the expansion of the state's ability to assert jurisdiction); see also MITSUE INAZUMI, UNIVERSAL JURISDICTION IN MODERN INTERNATIONAL LAW: EXPANSION OF NATIONAL JuRISDICTION FOR PROSECUTING SERIOUS CRIMES UNDER INTERNATIONAL LAW 132-48 (2005) (examining the status of universal jurisdiction in customary international law).

103 See RESTATEMENT (THIRD), supra note 29, at $\S 404$ (explaining state jurisdiction as it relates to activities within and outside state territory); see also CRAWFORD, supra note 100, at 467-71 (expanding on the reach of state jurisdiction under international law). 
[Vol. 38:4

tain international crimes, such as genocide, regardless of any connection between the crime and the prosecuting state.104 Universal jurisdiction is a form of cosmopolitan intervention to render corrective justice when the state with the primary responsibility to prosecute and punish is unable or unwilling to do so. Universal jurisdiction signifies the idea of shared responsibility in terms of punishing those who have committed mass or grave crimes such as genocide. Several countries have invoked universal jurisdiction to try Rwandans for atrocities committed during the Rwanda genocide. ${ }^{105}$

\subsection{Responsibility to Protect (R2P)}

$\mathrm{R} 2 \mathrm{P}$ is the front end of the spectrum of shared responsibility. The doctrine was formally introduced on the international level at the U.N. World Summit in 2005, where the heads of states and governments of 170 states, after affirming the primary responsibility of governments to protect their citizens from crimes such as genocide, 106 endorsed the idea of the international community shouldering a secondary responsibility if and when those with the primary

104 An example of a universal jurisdiction law is found in the German Code of Crimes Against International Law. Section 1 of the Code provides: "This Act shall apply to all criminal offences against international law designed under this Act, to serious criminal offences designated therein even when the offences was committed abroad and bears no relation to Germany." See Gerhard WERLE, PRINCIPLES OF INTERNATIONAL CRIMINAL LAW 406 (2005).

105 Belgium, Canada, and the Netherlands (among others) have indicted and prosecuted genocidaires. Belgium, for example, prosecuted two nuns in connection with the Rwanda genocide.

106 G.A. Res. 60/1, 2005 World Summit Outcome (Sept. 15, 2005), ๆ 138, available at http://www.who.int/hiv/universalaccess2010/worldsummit.pdf [https://perma.cc/2A5T-LSAH] ("Each individual State has the responsibility to protect its populations from genocide, war crimes, ethnic cleansing and crimes against humanity."). 
responsibility are unable or unwilling to discharge their responsibilities. 107 The doctrine was incorporated in qualified form into Security Council Resolution 1674. ${ }^{108}$ To ensure that the veto power is not employed to prevent intervention to avert or to stop atrocities, the International Committee on Intervention and State Sovereignty (ICISS) ${ }^{109}$ and other groups have suggested that there be a "code of conduct" for the Permanent Five as to when not to use their veto powers ("constructive abstention"). 110 Perhaps that is what we saw with SC Resolution 1973 in relation to Libya.111 China and Russia abstained, which allowed for the adoption of the resolution authorizing intervention. ${ }^{112}$

Although the international agreement on R2P does not explicitly entertain ideas of unilateral or collective responsibility outside the

107 Id. at I 139 ("The international community, through the United Nations, also has the responsibility to use appropriate diplomatic, humanitarian and other peaceful means, in accordance with Chapters VI and VIII of the Charter, to help protect populations from genocide, war crimes, ethnic cleansing and crimes against humanity. In this context, we are prepared to take collective action, in a timely and decisive manner, through the Security Council, in accordance with the Charter, including Chapter VII[.]").

108 S.C. Res. 1674, I 26 (Apr. 28, 2006) (“The Security Council . . . [n]otes that the deliberate targeting of civilians and other protected persons, and the commission of systematic, flagrant and widespread violations of international humanitarian and human rights law in situations of armed conflict, may constitute a threat to international peace and security, and, reaffirms in this regard its readiness to consider such situations and, where necessary, to adopt appropriate steps.") (emphasis in original).

109 ICISS was composed of independent experts and the group was convened by the Canadian government to explore ways in which the international community could respond to gross and systematic violations of human rights. It is ICISS that produced the report that proposed the idea of R2P. See generally THE INTERNATIONAL COMMISSION ON INTERVENTION AND STATE SOVEREIGNTY (ICISS), RESPONSIBILITY TO PROTECT (2001), available at http://responsibilitytoprotect.org/ICISS\%20Report.pdf [https:/ / perma.cc/Y3J5-NP6E].

110 The Permanent Five refers to the five major powers (China, France, Russia, United Kingdom, and United States), who are permanent members of the United Nations Security Council each possessing a veto power over substantive matters that come before the Council and with which they disagree.

111 See S.C. Res. 1973 (Mar. 17, 2011) (reviewing the resolutions eventually adopted by the Security Council). The vote was 10-0-5. China, Russia, Brazil, Germany and India abstained.

112 But the perception (not an unreasonable one) that NATO used the authorization under Resolution 1973 to engage in unauthorized regime change rather than protecting vulnerable people (especially in Benghazi) from the threat of the Libyan government, made it tougher to get Russia and China to go along with a Security Council authorized military response to the Syrian crisis or referring the Syrian situation to the International Criminal Court (ICC). 
Security Council or the U.N. Process, given the seriousness of crimes such as genocide, it would be utterly inconceivable or unimaginable that states or regional groupings are prevented to act either individually or collectively if the Security Council fails to act when there is an imminent threat of the kind that occurred in Rwanda.113 The Security Council is the first port of call on any matter of military intervention for protection purposes, 114 but there are other organizations, such as the General Assembly 115 or regional and sub-regional organizations, that could act as ports of call as well. After all, as early as

113 Indeed, military intervention from individual or groups of states for the protection of victims from genocide and other mass atrocities is not without precedence. Thus, "England, France, and Russia intervened in Greece in 1827 to stop massacres by Turkey, and France intervened again in Syria in 1860, to stop the killings of Maronite Christians. Various European powers also intervened in defence of Christians in Crete (1866-68), the Balkans (1875-78), and Macedonia (1903-08). . . India sent troops into Bangladesh in 1971 to protect Bengalis for the murderous rampage of a military dictatorship in West Pakistan." Ramesh Thakur, The Use of International Force to Prevent or Halt Atrocities: From Humanitarian Intervention to the Responsibility to Protect, in THE OXFORD HANDBOOK OF INTERNATIONAL HUMAN RigHTS LAW 815, 819 (Dinah Shelton ed., 2013). And NATO intervened in Kosovo. See LARRY MAY, GENOCIDE: A NORMATIVE ACCOUNT 228 (2010) (“It would be a failure of monumental proportions if the international community felt that it was powerless to go to the aid of an oppressed people that was facing annihilation at the hands of a tyrannical government of the sort that Nazi Germany epitomized.").

114 The International Commission on Intervention and State Sovereignty (ICISS) in 2001 made this point clearly and directly when it said: "We have made abundantly clear our view that the Security Council should be the first port of call on any matter relating to military intervention for human protection purposes. But the question remains whether it should be the last. In view of the Council's past inability or unwillingness to fulfill the role expected of it, if the Security Council expressly rejects a proposal for intervention where humanitarian or human rights issues are significantly at stake, or the Council fails to deal with such a proposal within a reasonable time, it is difficult to argue that alternative means of discharging the responsibility to protect can be entirely discounted." See ICISS, supra note 109 , at 53.

115 The reluctance to allow military intervention without Security Council authorization is based textually on Article 2(4) of the UN Charter, which affirms "the territorial integrity and political independence" of member states and prohibits members not to engage in "the threat or use of force" to undermine the integrity and independence of fellow member states. But it also based on a sensible policy that is intended to minimize the occasions of states using human rights as an excuse to intervene for other, impermissible, motives. That legitimate worry could be addressed without a blanket prohibition of intervention unless authorized by the Security Council, for permanent members of the Security Council could veto authorization for similarly impermissible purposes. You cannot redeem impermissible motives of the intervener by endorsing the impermissible motive of the preventer of collective action. So, perhaps one way to deal with the legitimate worry is, for example, in the event that there is a veto of a resolution to intervene by a permanent member of the Security Council which has garnered the required supermajority 
1948 the international community adopted the position - through the Genocide Convention - that genocide is not simply a crime within a particular community, but "a crime under international law," and a crime which member states pledged "to prevent and to punish."116

It is important to note, as I shall emphasize throughout this article, that R2P is not just about military intervention. ${ }^{117}$ Perhaps it ought not to be primarily about military intervention if it is to perform its preventive function, which is said to be "the single most important dimension" 118 of the doctrine's purpose. If the international community has waited until there is a need for military intervention, then in many cases it has probably waited too long. After all, it is only when "appropriate diplomatic, humanitarian and other peaceful means, in accordance with Chapters VI and VII of the U.N. Charter" 119 have failed to avert the threat of genocide that military intervention as an option is on the table. R2P is distinguished from the general and traditional notions of humanitarian intervention by the idea that prevention is central to the whole enterprise, as well as the fact that peaceful means are to be tried to achieve the preventive purpose before military intervention is authorized.120

vote (nine votes), then the issue would go to the General Assembly for a vote for or against authorization (which incidentally would also declare whether there is a genocide threat or attack). Reading the Charter in the best light (consistent with the best aspirations of the preamble) would suggest that this action of the Assembly will not be ultra vires. For a similar statement, see Dworkin, A New Philosophy, supra note 101 , at $25-26$.

116 Convention on Genocide, supra note 22, art. 1.22

117 In fact, member states in the World Summit Outcome Document expressed this sentiment directly and clearly. Member states acknowledged the international community had responsibility to "use appropriate diplomatic, humanitarian and other peaceful means, in accordance with Chapters VI and VII of the Charter of the United Nations, to help protect populations from genocide, war crimes, ethnic cleansing and crimes against humanity." See 2005 World Summit Outcome, supra note 106, at 139. But military intervention "does seem to succeed at stopping the killing once it has begun[.]" Krain, supra note 15, at 574; see also Matthew Krain, International Intervention and the Severity of Genocide and Politicides, 49 INT'L. STUD. Q. 363 (2005) (studying the effectiveness of military intervention in genocide and politicide).

118 ICISS, supra note 109 , at XI.

1192005 World Summit Outcome, supra note 106, at 138.

120 See Gareth Evans, From Humanitarian Intervention to the Responsibility to Protect, 24 WIs. INT'L L. J. 703, 708 (2006) (discussing the new ways of characterizing humanitarian intervention and the responsibility to protect). 


\subsection{Universal Jurisdiction and R2P: Comparison and Summary}

Universal jurisdiction, as I use it in this article, is a customary international legal principle, while $\mathrm{R} 2 \mathrm{P}$ is a doctrine that has been announced by the international community with uncertain legal pedigree. But to the extent that the doctrine arose out of a meeting of heads of states and governments, and has been endorsed in some form by the Security Council in a resolution and in action, R2P is not without legitimate source. ${ }^{121}$

While universal jurisdiction permits states to act unilaterally and in their individual capacity, R2P places the responsibility on the international community as a corporate body. States are to work through the United Nations when the intervention is peaceful, but if peaceful means are inadequate, states are to act through the Security Council consistent with the Council's Chapter VII authority and in compliance with the purposes and principles of the Charter.

Universal jurisdiction authorizes states to punish after the fact those who have committed atrocities (corrective and remedial), while R2P is primarily about preventing the occurrence of or stopping atrocities. In relation to genocide, the two doctrines are the international analogues of what the Genocide Convention requires of every state: that it "undertake to prevent and to punish." 122

The crimes for which R2P is deployed 123 are essentially the same crimes that are subject to universal jurisdiction. Ethnic cleansing is the only crime that $\mathrm{R} 2 \mathrm{P}$ protects that is not part of the jus cogens norms for which universal jurisdiction can be asserted. But ethnic cleansing could be seen as functionally equivalent to genocide if the removal of a group is intended to bring about its demise by scattering members. ${ }^{124}$ At any rate, for our purpose it does not matter

121 Alex Bellamy shows that nine of the ten recent crises on which the Security Council has acted "referred explicitly to [R2P] and made provision for the protection of populations." Alex J. Bellamy, The Responsibility to Protect Turns Ten, 29 ETHICS \& INT'L AFF. 161, 166 (2015).

122 Genocide Convention, supra note 22, at art. 1.

123 Those crimes are genocide, war crimes, crimes against humanity, and ethnic cleansing.

124 See Application of Genocide Convention (Bosn. \& Herz. v. Serb. and Montenegro), supra note 41 , at 84 . (observing that neither the intent nor the operation to make an area ethnically homogenous "can as such be designated as genocide[,]" and adding that " $[\mathrm{t}]$ his is not to say that acts described as 'ethnic cleansing' may never constitute genocide, if they are such as to be characterized as, for example, 'deliberately inflicting on the group conditions of life calculated to bring about its physical destruction in whole or in part' ...."); see also Application of Convention on 
whether the list of crimes covered by one doctrine is identical to the list in the other, for the crime which is the focus of our inquiry (genocide) is listed prominently in both.

Furthermore, both universal jurisdiction and R2P recognize and affirm the importance of national communities (states) to belonging and protection. We turn to those communities as an initial matter to take primary responsibility (and right of action) for the protection of the rights of members of those communities. The reason we look to those communities first is not just because that is where the best and most effective form of protection and promotion can take place, but also because we make a normative judgment that states (national communities) are "sites of collective freedom" 125 providing "framework of participation." 126

At the same time, however, these doctrines imagine another community - the international community - to which individuals belong and from which they expect protection and corrective action in the event that the national community is unable or unwilling to provide such protection or corrective action. In this sense, the two international doctrines affirm national communities while also gesturing towards cosmopolitanism. ${ }^{127}$ The state is seen as a site of primary "membership, allegiance, obligation, and political mobilization" on a globe that presents other viable possibilities, including the international community itself. ${ }^{28}$ Understood in this way, it makes a great deal of sense why both doctrines limit the domains of their operation to a very limited number of crimes that are regarded as

Prevention and Punishment of Crime of Genocide (Croatia v. Serbia), supra note 35, at 376 (clarifying that forced displacement does not necessarily constitute genocide within the meaning of the Convention). But see, SCHABAS, supra note 20 at 221234. In relation to Article II(e) of the Genocide Convention, which lists the forcible transfer of the children of one group, the ICJ recently observed that such an act "can also entail the intent to destroy the group physically . . . since its can have consequences for the group's capacity to renew itself, and hence to ensure its long-term survival." Application of Convention on Prevention and Punishment of Crime of Genocide (Croatia v. Serbia), supra note 35, at $₫ 136$.

125 CONNOLLY, supra note 2, at 24; see also id. at 201.

126 See Ruth Gavison, Taking States Seriously, in READING WALZER 44 (Yitzhak Benbaji \& Naomi Sussmann eds., 2014).

127 This gesture towards nationalism and cosmopolitanism as a general matter is defended in David MiLler, NATIONAL RESPONSIBILITY AND GLOBAL JUSTICE (2007).

128 CONNOLly, supra note 2, at 215 ("Perhaps today the state must be thought and lived as one site of membership, allegiance, obligation, and political mobilization on a globe that presents other viable possibilities of identification, inside and outside state boundaries."). 
crimes against all of us. The most apt example is the crime of genocide, a crime whose perpetrators are regarded as hostis humani generis (enemies of humankind). I shall explain later what the notions of "crimes against all humankind" and the idea of hostis humani generis entail.

\subsection{What Makes Genocide an Offense Eligible for R2P and Universal Jurisdiction: Current Accounts}

Before I develop the constitutive thesis of the international response to genocide, let me briefly canvas the available explanations for why international response to genocide or threatened genocide is justified.

\subsubsection{Genocide "Shocks the Conscience"}

Many scholars and international tribunals have asserted that what makes genocide and a few other international crimes candidates for intervention either at the front or the back end is the heinousness or shocking nature of the crime. Referring to jus cogens norms, which include genocide and are subject to universal jurisdiction, Professor M. Cherif Bassouni claims that the only way to understand their existence is to realize that "certain crimes affect the interests of the world community as a whole because they threaten the peace and security of humankind and they shock the conscience of humanity." 129 The sentiment that it is the shocking or "heinous" na-

129 M. Cherif Bassiouni, International Crimes: Jus Cogens and Obligatio Erga Omnes, 59 LAW \& CONTEMP. PROBS. 63, 69 (1996) (emphasis added). 
ture of the crime that makes genocide subject to universal jurisdiction is repeated by many other scholars ${ }^{130}$ and international tribunals. ${ }^{131}$ The same sentiment is expressed in relation to international military intervention to prevent genocide. Thus, the noted political theorist Michael Walzer in his deservedly famous book, Just and Unjust Wars, argues that humanitarian intervention (such as R2P) is justified in response to acts that "shock the conscience of mankind," 132 and he puts genocide at the end of the "nastiness" spectrum. ${ }^{133}$ More recently, the International Commission on Intervention and State Sovereignty (ICISS) expressed a similar view concluding that genocide and other international crimes are "conscience shocking" and hence grounds for international intervention at the front end.134 Even more recently, a former United Nations Assistant Secretary-

130 See, e.g., Stephen Macedo, Introduction, in UNIVERSAL JURISDICTION: NATIONAL COURTS AND THE PROSECUTION OF SERIOUS CRIMES UNDER INTERNATIONAL LAW 1, 4 (Stephen Macedo ed., 2004) (describing the shocking nature of crimes as contributing to their inclusion in global jurisdiction); Leila Nadya Sadat, Redefining Universal Jurisdiction, 35 NEW ENG. L. REV. 241, 244 (2001) ("Application of the theory of universal jurisdiction . . . is predicated on largely on the notion that some crimes are so heinous that they offend the interest of all humanity -indeed, they imperil civilization itself."); Donald Francis Donovan \& Anthea Roberts, The Emerging Recognition of Universal Civil Jurisdiction, 100 AM. J. INT'L L. 142, 143 (2006) ("In modern times, universal jurisdiction has been founded on the sheer heinousness of certain crimes, such as genocide and torture, which are universally condemned and which every state has an interest in repressing even in the absence of traditional connecting factors.").

131 Reservations to Convention on Prevention and Punishment of Crime of Genocide, supra note 31, at 23 (stating that Genocide is "a denial of the right of existence of the entire human groups, a denial which shocks the conscience of mankind[.]"). This statement has been quoted in subsequent ICJ decisions. See, e.g., Legality of the Threat or Use of Nuclear Weapons, Advisory Opinion, 1996 I.C.J. Rep. 226, 31 (July 8, 1996); Application of the Convention on Prevention and Punishment of Crime of Genocide (Bosn. \& Herz. v. Serb. and Montenegro), supra note 41 , at 161.

132 See Michael Walzer, Just and UnJust Wars: A Moral Argument With HistoricAl Illustrations 107 (4th ed. 2006). See also Michael Walzer, The Moral Standing of States: A Response to Four Critics, 9 PHIL. \& PUB. AfF. 209 (1980) (responding to criticisms of his book, Just and Unjust Wars). This sentiment has powerful pedigree: John Stuart Mill is said to have expressed the view that intervention is justified when "a state renders itself guilty of cruelties and persecution of its nationals in such a way as to deny their fundamental human rights and to shock the conscience of mankind." See L. OPPENHEIM, INTERNATIONAL LAW: A TREATISE 312 (8th ed. 1955) (giving a brief account of the position of Mill), see also John Stuart Mill, A Few Words on Non-Intervention, in DisSERTATIONS AND DISCUSSIONS: POLITICAL, PHILOSOPHICAL, AND HISTORICAL Vol. 3 153, 171-72 (1867).

133 See Michael Walzer, ThinKING POLITICALLY: EsSAYs IN POLITICAL THEORY 238 (David Miller ed., 2007).

134 ICISS, supra note 109 , at 33. 
General and one of the principal authors of The Responsibility to Protect expressed a similar sentiment. Ramesh Thakur, who is currently serving as a professor of international relations at the Australian National University, observes that: " $\mathrm{R} 2 \mathrm{P}$ is the normative instrument of choice to convert a shocked international conscience into effective collective action." 135

The observation that genocide is heinous or that it shocks the conscience seems unremarkably obvious. The idea of eliminating an entire group from the face of the earth to chase the horrible fantasy of creating a pure community ought to shock people. But as an explanation why it is one of only a handful of international crimes that should be subject to universal jurisdiction or to R2P intervention, it does not seem to be entirely persuasive. First, as I have explained in another article, the claim is under-inclusive. ${ }^{136}$ There are many crimes, such as forced disappearances, wide extra-judicial killings, and terrorist acts (e.g. beheadings), which are heinous and ought to shock our conscience, yet are not part of the list. 137

Second, and more importantly, those who rely on "heinousness" and "shock of the mind" to justify the list of crimes eligible for universal jurisdiction and R2P intervention do not supply any principled way by which, as a normative matter, we decide which crimes are properly characterized as such. Without more guidance, it would be impossible to justify the existing list or to advocate addition to or subtraction from it. That is, a coherent account justifying the limited current list both in relation to universal jurisdiction and R2P will also enable us to determine whether or not the list should be lengthened or shortened.

But perhaps the reason why genocide shocks the mind is because it is thought of as a crime that causes large-scale harm. ${ }^{138} \mathrm{Un}$ der this understanding, it is the scale of the destruction rather than

135 Thakur, supra note 113, at 817; see also Ramesh Thakur, $R 2 P^{\prime}$ 's 'Structural' Problems: A Response to Roland Paris, 22 InT'L PEACEKEEPING 11, 23 (2015).

136 See Adeno Addis, Imagining the International Community: The Constitutive Dimension of Universal Jurisdiction, 31 HUM. RTS. Q. 129, 139 (2009) ("It is also underinclusive to the extent that many crimes that devalue and even destroy human life itself are not part of the list of crimes that are heinous and diminish all of us.").

137 Id. at 139.

138 See BEATRICE I. BONAFÉ, THE RELATIONSHIP BETWEEN STATE AND INDIVIDUAL RESPONSIBILITY FOR INTERNATIONAL CRIMES 71 (2009) (stating that "International crimes are offences which require to be carried out on such a large scale that the participations or at least the support of the state apparatus has often been present."). 
the nature of the crime that makes it shocking. On reflection, however, this argument is not entirely persuasive. For there to be a crime of genocide the law does not require that large-scale atrocities be committed. Indeed, technically there could be a genocidal crime even with a relatively small number of direct victims - deaths, injuries, etc. - as long as the requisite intent to destroy the particular group in whole or in part is present. International tribunals seem to agree with this observation. Thus, for example, the International Criminal Tribunal for the Former Yugoslavia has held that genocide could occur even in circumstances of small-scale killings by a single individual who engages in those activities with the intent of destroying the group, even when that intent is entirely unrealistic. ${ }^{139}$ Thus, to the extent that genocide shocks the mind, it must be because of the nature of the crime rather than the number of its victims. ${ }^{140}$

Even if one were to agree on a list, one would still need to show why and how these crimes affect "the interest of all humanity,"141 for often the heinousness of the crime is linked to its effect on the interests of the international community - the "great losses to humanity" that are "inflicted" 142 by it. That is, these heinous crimes invite intervention because they affect the interests of the international community as a whole. ${ }^{143}$ The question remains as to what precisely is the interest of the international community that is uniquely implicated by the occurrence of genocide in one remote part of the world? Those who advance "shock" and "heinousness" as grounds for justifying the current list either for the assertion of universal jurisdiction or intervention under R2P have not effectively responded to this question.

139 Prosecutor v. Jelisi, Case No. IT-95-10-T, Judgment, ๆ 66 (Int'1 Crim. Trib. for the Former Yugoslavia, Dec. 14, 1999) (explaining that the mens rea distinguishes genocide). I must point out here, however, that a prominent legal scholar on genocide, William Schabas, believes that we should infer large scale from the definition of genocide. See ScHABAS, supra note 20.

140 See Margaret M. De Guzman, When are International Crimes Just Cause for War, 55 VA. J. INT'L L. 73, 92 (2014) (Presenting that the just cause threshold for humanitarian intervention is qualitative, based on the nature of the time, not quantitative, based on the number of victims).

141 Sadat, supra note 130, at 244.

142 Convention on Prevention and Punishment of Crime of Genocide, supra note 22, at Preamble.

143 The Rome Statute of the ICC deems the crimes listed in the statute as "the most serious crimes of concern to the international community as a whole" and ones that "shock the conscience of humanity." Rome Statute of the International Criminal Court, supra note 26, at pmbl. 
[Vol. 38:4

\subsubsection{Genocide and Chaos}

Another explanation that may justify the use of universal jurisdiction and R2P intervention in relation to crimes such as genocide is that such crimes often occur in circumstances of political, social and legal chaos and without international intervention further chaos will ensue and perpetrators will go unpunished. Under circumstances of genocide, legal and political systems and infrastructures are under tremendous stress and invariably unable to protect victims or to punish perpetrators. Even more likely, the argument would go, is the fact that the government that has the primary responsibility to protect and to correct will itself have been implicated in the genocidal outbreak. It will be utterly naïve, the argument continues, to expect that the government will discharge its primary responsibility to respect, protect, or correct under those circumstances. The action of the Rwandan government during the genocide and the Sudanese government's attitude to the events in Darfur (the first acknowledged genocide of the $21^{\text {st }}$ century) are perhaps good examples of such circumstance. ${ }^{144}$

144 The estimate is that anywhere between 200,000 and 500,000 people have been killed in the Darfur region. See Samuel Totten, Genocide in Darfur, in CENTURIES OF GENOCIDE, at 513. Totten places the figure between 300,000 and 400,000, but others vary between 200,000 and 500,000. Even though there are disputes about the numbers, there is increasing consensus that genocide was committed in Darfur. In 2004, the United States Congress passed a resolution declaring the situation in Darfur a genocide; and there is a warrant out for the President of Sudan, Omar alBashir, on genocide charges from the ICC. The arrest warrant was issued on March 4, 2009 pursuant to Security Council Resolution 1593, which referred the Darfur issue to the Court. Since Sudan is not a signatory to the Rome Statute, the only way that the Court could assert jurisdiction on President al-Bashir was if the Security Council (pursuant to article 13(b) of the Rome Statute) referred the matter to it (which is what happened here). But even that move does not seem to have led us any closer to the apprehension of al-Bashir. Indeed, a recent event shows how utterly powerless the ICC is in terms of getting those it has indicted before the Court, especially if those individuals have powerful friends to protect them. In June 2015, al-Bashir flew to South Africa to attend a meeting of the African Union. A South African organization sought an order from a court in South Africa to get him arrested and delivered to the ICC pursuant to the warrant. Since South Africa is signatory to the Rome Statute, the applicants for the arrest argued, it is required to apprehend and delivered al-Bashir to the ICC. The South Africa High Court instructed the nation's authorities to prevent al-Bashir from leaving South Africa until the Court has made a determination whether or not he should be arrested pursuant to the ICC warrant. However, al-Bashir was allowed to fly back to Sudan, in violation of South Africa's treaty commitment, and according to the High Court of South 
On reflection, however, it is not quite clear that this would be a sufficient ground for distinguishing the listed crimes from other crimes. There are many other crimes, such as extra-judicial killings and torture, which are often committed by governments or their supporters against those considered to be internal enemies or challenges to the established order and are left as unpunished as those on the list of crimes said to be subject to universal jurisdiction and to intervention under R2P. And although most of the crimes on the $\mathrm{R} 2 \mathrm{P}$ list are committed in the course of an armed conflict (often a civil war), a time where legal infrastructures are in serious stress, as I indicated earlier there are other crimes (such as mass torture), which tend to occur under such circumstances as well. In any case, in relation to the crime with which we are concerned here (genocide), an armed conflict is not necessary ${ }^{145}$ and there are numerous examples that illustrate this (unless of course one sees the genocide itself as an armed conflict, but that would be unhelpfully circular).

Even if it were the case that genocide is one of the few crimes that is likely to go unpunished if there is no international intervention, there is still the question as to why such intervention is considered to be in the interests of the international community or what interest of the international community is so affected that international intervention is required.

Now, some, including M. Cherif Bassouni, have argued that international intervention in relation to jus cogen norms (which includes genocide) may be partly explained by the chaos that would ensue not only in relation to the particular country, but in relation to the rest of the world as well, especially neighboring countries.

\footnotetext{
Africa, in violation of the South Africa Constitution, as well. See Norimitsu Onishi, Omar al-Bashir, Leaving South Africa, Eludes Arrest Again, N.Y. TIMES (June 15, 2015) (reporting that al-Bashir flew out of South Africa just hours before a South African court ruled that the government was legally required to arrest him); Somini Sengupta, Omar Bashir Case Shows International Criminal Court's Limitations, N.Y. TIMES (June 15, 2015) (recounting that South Africa let Mr. Bashir fly home despite an order from South Africa's High Court instructing the nation's authorities to prevent him from leaving the country); Norimitsu Onishi, Bid by Omar al-Bashir of Sudan to Avoid Arrest Is Tested in South Africa, N.Y. TIMES (June 14, 2015). African leaders and the African Union (which is their trade union) protect club members even if it that means doing so in violation of their domestic and international obligations.

145 See Convention on Prevention and Punishment of Crime of Genocide, supra note 22, at art. 1 ("The Contracting Parties confirm that genocide, whether committed in time of peace or in time of war, is a crime under international law which they undertake to prevent and to punish.").
} 
Bassouni claims "certain crimes affect the interests of the world community as a whole because they threaten the peace and security of humankind and they shock the conscience of humanity." 146 It is true that genocide that is part of an intense civil war is likely to destabilize neighboring countries, but such destabilization seems to be no more a threat to the peace and security of the international community (or humankind) than if the civil war did not lead to genocide. Indeed, somewhat perversely, the destruction of the group would reduce one of the most significant causes of destabilization: the flow of refugees! So, the "international chaos" argument is no more persuasive than arguments that are premised on the notion of "national chaos."

\subsection{International Response to Genocide: Ways of Imagining the International Community}

As I have argued in the last sub-section, the instrumental arguments that are offered to justify the assertion of universal jurisdiction and intervention under $\mathrm{R} 2 \mathrm{P}$ in relation to crimes such as genocide are unpersuasive. However, even if those instrumental arguments are found to be persuasive, I shall argue in this section that the international doctrines for the suppression (R2P) and punishment (universal jurisdiction) of certain international crimes such as genocide cannot be explained in instrumental terms only. These two doctrines have another, less articulated purpose. They have constitutive dimensions as well. They are partly processes through which the international community imagines its identity as a counter to the destructive communities imagined through genocidal acts. ${ }^{147}$ Neglect of the constitutive dimension, I shall argue, leads to an incomplete analysis of the function of these two doctrines. The

146 M. Cherif Bassouni, International Crimes: Jus Cogens and Obligations Erga Omnes, LAW \& CONTEMP. PROBS., 63, 69 (1996) (emphasis added).

147 As I explained earlier, the idea of imagined communities is that of Benedict Anderson's. BENEDICT ANDERSON, IMAGINED COMMUNITIES: REFLECTIONS ON THE ORIGIN AND SPREAD OF NATIONALISM, supra note 44 . The role of international norms as means of imagining an internal community was expressed by HEDLEY BULL, THE ANARCHIC SOCIETY: A STUDY OF ORDER IN WORLD POLITICS 80 (1977) (describing how, "[norms of cosmopolitan justice] are ideals which seek to spell out what is right or good for the world as a whole, for an imagined civitas maxima or cosmopolitan society to which all individuals belong and to which their interests should be subordinated."). 
point could even be made about legal norms, generally. Whether jurisdictional or substantive, it is erroneous to see legal norms only in instrumental terms, as means of doing (to prevent or punish genocide). They are also ways of being, ways through which we define who we are or aspire to be. ${ }^{148}$

The secondary responsibility that the international community has assumed to forestall genocide and punish genocidaires through universal jurisdiction and $\mathrm{R} 2 \mathrm{P}$ is simultaneously instrumental (seeks to protect vulnerable groups) and constitutive (defines or imagines the identity of the international community).

Communities, just like individuals, need the Other to constitute and consolidate their identities. That is, identities are defined relationally. ${ }^{149}$ As William E. Connolly notes, "difference is a requirement built into the logic of identity, and the construction of otherness is a temptation that readily insinuates itself into that logic." 150 Indeed, it is beyond "temptation." But what is this Other against whom the international community would be able to define itself here? Against whom does the international community imagine itself?

148 Here, I am siding with Joseph Raz in his dispute with Ronald Dworkin in relation to whether law is to be understood exclusively as a means of doing (instrumentally) or whether it should also partly be seen as a means of being (as a means of constituting who we are). Dworkin accuses Raz of misunderstanding the nature of law when the latter claims that "[i]n large measure what we study when we study the nature of law is the nature of our own self-understanding." Joseph Raz, Can There be a Theory of Law, in BLACKWELL GUIDE TO THE PHILOSOPHY OF LAW AND Legal Theory 324, 331 (Martin P. Golding \& William A. Edmunds eds., 2005). Dworkin asserts, in my view somewhat too quickly, that law has no such role: "[i]f we want to study our own self-consciousness we would do much better to turn to fiction, politics, biography, depth psychology, and social science. We reflect on the character of law to know what we must do, not what we are." RONALD DWORKIN, JUSTICE IN ROBS 229 (2006). It is somewhat puzzling that Dworkin who has always viewed law as an interpretive enterprise, deeply linked to a particular culture and history, would make the claim that there is a sharp distinction between who we are and what we are supposed to do. What we are to do is to a great extent suggested by who we are. In any case, I shall argue that jurisdiction (and by implication, law) is constitutive of who we are as it is a guide of what we are meant to do.

149 See Addis, Imagining the Homeland from Afar: Community and Peoplehood in the Age of the Diaspora, supra note 3, at 988.

150 CONNOLLY, supra note 52, at 9. 


\subsubsection{Homo Sapiens and Nature: A Way of Imagining the International Community?}

At the beginning of his account of the Rwanda genocide, Peter Gourevitch tells a story of a self-proclaimed pygmy he met when he visited Rwanda in 1995, soon after the genocide. The pygmy announced that he was a pygmy, though he was five and a half feet tall, and perhaps would not have been assumed to be a pygmy had he not announced that he was. Gourevitch claims that this self-identification is a way of "declaring himself . . . to be ... as a fellow outsider," "setting himself apart from the matter of Hutu and Tutsi."151

From my point of view, the pygmy's observation about universalism and the unity of humankind was equally fascinating. He tells Gourevitch that it does not "matter if you are white or yellow or green or a black African Negro. The concept is Homo sapiens." 152 And then, as if that is not sufficient to lead to an international community of humankind, he adds "all humanity must unite together in the struggle against nature." 153 "Humanity's struggle to conquer nature ... is the only hope ... the only way for peace and reconciliation-all humanity one against nature." For the self-proclaimed pygmy, the positive traits that make us all humans are not sufficient bases for cultivating the international community. Nature too, forms the boundary against which we struggle, and must struggle together, for the purposes of surviving as Homo sapiens. All these ethnic and racial divisions that manifest themselves in mass crimes such as genocide are apparently distracting us from the real enemy: nature. But, of course, the self-proclaimed pygmy finally realizes that humanity is also part of nature and therefore nature cannot form the boundary.

To be sure, this is not the first time when the boundary between humans and other parts of nature have been used as a way of unifying humanity. For example, there are political theorists who have anchored the notion of human dignity in terms of the distinction between humans and other species - human dignity as an indication

151 Gourevitch, supra note 10, at 7 ("Pygmies were Rwanda's first inhabitants, a forest people, who were generally looked down upon by Hutu and Tutsi alike as vestigial, aboriginal lot."). The descendants of those pygmies are now called the Twa people and they constitute less than one percent of the Rwandan population.

152 Id. at 8. In academic speak, the global community envisioned here is a community of persons, not a community of nations or groups of any sort.

153 Id. 
of the higher rank that humans enjoy compared to other creates of nature. 154 Whether or not the notion of dignity can be understood in terms of the higher rank that humans enjoy among the rest of nature-and I have argued that it cannot be ${ }^{155}$ - the idea that this would therefore be the basis on which the international community imagines itself, as a community is rather thin. The notion that the struggle against nature will sufficiently unite the diverse human race so as to minimize conflicts within and among groups seems rather unpersuasive. ${ }^{156}$

\subsubsection{The International Community and the Outlaw Other- Another Way of Imagining the International Community}

\subsubsection{The International Community and Secondary Responsibility}

As emphasized throughout this article, the state has the primary responsibility to respect, protect and promote human rights within its territory and under its jurisdiction. It has the responsibility to forestall atrocity crimes such as genocide and to punish those who have committed such crimes. However, the state is often in circumstances of genocide either unable (there is total breakdown of legal infrastructure) or unwilling (because the state itself is involved in those crimes). The genocides in Rwanda, Nazi Germany, the Ottoman Empire, and Darfur (Sudan) are good examples. Under such circumstances, there is a need to place the responsibility on the international community, either through individual member states or collectively, to ensure that the responsibility is discharged. That is what universal jurisdiction and the responsibility to protect (R2P) are. The former urges states to take responsibility individually, while the latter encourages them to act collectively. The United Nations Millennium Declaration put the collective responsibility this way: "We recognize that in addition to our separate responsibilities

\footnotetext{
154 See George Kateb, Human Dignity (2011).

155 Adeno Addis, The Role of Human Dignity in a World of Plural Values and Ethical Commitments, 31 NeTH. Q. HuM. RTs. 403 (2013).

156 The debate on whether and how the world should respond to climate change is an instructive example.
} 
to our individual societies, we have a collective responsibility to uphold the principles of human dignity, equality and equity at the global level."157

The primary responsibility ("our separate responsibilities to our individual societies") is what we might want to refer to as hard responsibility. Hard responsibility is one that is imposed on the relevant entity as a firm duty. Here, the relevant entity is required to act in a particular way - to remedy a violation or to forestall one. Not acting in the required way is a breach of a duty and itself a legal wrong. States, either through conventional or customary law, have assumed obligations to respect, protect and promote human rights within their territories and/or their jurisdictions. Indeed, some commentators have even argued that the notion of sovereignty itself imposes a duty on state authorities to treat their citizens in a particular way. Sovereignty is not just the right to rule but also the obligation to rule in a particular way. ${ }^{158}$

The secondary responsibility to which I have referred earlier might be labeled as soft responsibility. It comes not in the form of a firm duty but as a legal permission suffused with moral expectation. Universal jurisdiction for certain international crimes, including genocide, is an example of a soft responsibility. R2P straddles the hard/soft divide. Some consider it a firm duty. ${ }^{159}$

157 U.N. Millennium Declaration, G.A, Res. 55/2, U.N. Doc. A/55/L.2, at 92 (Sept. 8, 2002).

158 See ICISS, supra note 109 at 8, 2.14.; see also, Thakur, supra note 113 , at 818 ("In recent times, sovereignty has been reconceived as being instrumental. Its validation rests not in a mystical reification of the state, but in its utility as a tool for the state serving the interests of the citizens. International forms and precepts of governance must confirm to international norms and standards of state conduct. That is, sovereignty must be exercised with due responsibility."); see also FRANCIS M. Deng ET AL, SOVEREIGNTY AS Responsibility: Conflict MANAGEMENT IN AFRICA (1996); Ronald Dworkin, A New Philosophy for International Law, supra note 101, at 19 ("The legitimacy of coercive governments requires . . . that people play some genuine, even minimal and indirect, role in their own government. Political theorists disagree about what kind of participation is essential in different forms of government, but it is generally understood (even if his is far from universally provided) that some form of wide-spread suffrage in the election of officials is both necessary and sufficient within a distinct political community."); see also, LUKE GLANVILLE, SOVEREIGNTY \& THE RESPONSIBILITY TO PROTECT: A NEW HISTORY (2014) (Making and defending the claim that sovereignty has always entailed responsibility as well as authority in this detailed historical survey of sovereignty.).

159 See Alex J Bellamy, The Responsibility to Protect Turns Ten, supra note 121, at 182 ("In its first ten years, RtoP has emerged as an international norm. With only a tiny handful of exceptions, states accept that they have made a commitment to RtoP and agree on its fundamental components."); Luke Glanville, The International Community's Responsibility to Protect, 2 GLOBAL RESPONSIBILITY TO PROTECT, 287, 306 
Wherever one puts universal jurisdiction on the hard/soft responsibility divide or on the hard/soft spectrum, it is clear that R2P and universal jurisdiction represent two facets of the international community's responsibility to prevent atrocity crimes (R2P) or to punish those who have engaged in such atrocities (universal jurisdiction). Both doctrines concern crimes to which the primary responsibility holders have not responded.

Another way to look at the relationship between primary and secondary responsibilities is to think of primary responsibility as imposing an obligation on each state to improve its political legitimacy, "legitimacy of its own coercive government," but that obligation is to be discharged in a way that will "improve the overall international system." 160 As I shall explain in the next section, part of that international order is the cultivation of and respect for an international order of plurality and human diversity. When that is threatened, the international community, either individually or collectively, will have a secondary responsibility to intervene to protect it.

\subsubsection{Hostis Humani Generis: The Genocidaire as The Enemy of All of Us}

As the International Court of Justice noted in its 1951 Advisory Opinion, genocide has a universal character both in terms of it condemnation and in terms "of the co-operation required 'in order to liberate mankind from such an odious scourge.'"161 Indeed, the Preamble to the Genocide Convention emphasizes that "genocide has

(2010) ("[T]he ICJ has confirmed that particular actors within the international community may bear a legal responsibility to prevent the occurrence of genocide, though serious questions remain about the range of actors upon which this responsibility may fall and the remedies available in those instances where actors fail to discharge their obligations.").

160 Dworkin, A New Philosophy for International Law, supra note 101, at 17. Dworkin argues that one way a state is "defective in its legitimacy [is] when it cannot protect those over whom it claims a monopoly of force from the invasions and pillage of other peoples." Id. See also Win-Chiat Lee, International Crimes and Universal Jurisdiction, in INTERNATIONAL CRIMINAL LAW AND PHILOSOPHY 15, 18 (Larry May and Zachary Hoskins eds., 2010).

161 See Reservations to Convention on Prevention of and Punishment of Genocide, supra note 31, at 23. The inside quotes are taken from the Preamble of the Convention, supra note 22 , at pmbl. 
inflicted great loss to humanity,"162 not just loss to a group or a country. The "international community as a whole" is taken to be a victim of genocide wherever that takes place. 163

In what sense is genocide in one part of the world an infliction of "a great loss to humanity"? Why is genocide considered to be of sufficient concern to the international community that the community either in its corporate capacity or through its individual members will intervene to stop its commission or punish perpetrators? The perpetrators of the crime of genocide in the context of universal jurisdiction are referred to as hostis humani generis - enemies of humankind. That is, genocide is apparently committed not just against the specific victims or the countries of which these victims are citizens, but against all of us.

In what sense are genocidaires enemies of humankind?164 One way in which genocide is an attack on humankind is that it undermines what Hannah Arendt calls the "salient characteristic of the human condition": the potential for and the reality of diversity. For Arendt, what made the Nazi crime an attack on the human condition was that it was "an attack upon human diversity as such, that is, upon a characteristic of the 'human status' without which the very words of 'mankind' or 'humanity' would be devoid of meaning." 165 Genocide is an attack on the very nature of what makes an international community what it is: a community of diverse peoples and diverse ways of being. The genocidaire's attempt to create a pure community (and in the process cure humanity of its salient

162 See Convention on Genocide, supra note 22, at pmbl.

163 William E. Conklin, The Exclusionary Boundary of the Early Modern International Community, 81 NordiC J. INT'L L. 135 (2012). See Vienna Convention on the Law of Treaties art. 53, May 23, 1969, 1155 U.N.T.S. 331; see also Vienna Convention on the Law of Treaties between States and International Organizations or between Organizations, U.N. Doc. A/CONF.129/15 (March 21, 1986).

164 The arguments in this section draw from an earlier article of mine. See Addis, Imagining the International Commuinity, supra note 136.

165 ARENDT, supra note 39, at 247. Michael Ignatieff makes a similar point:

"What it means to be a human being, what defines the very identity we share as a species, is the fact that we are differentiated by race, religion, ethnicity, and individual differences. These differentiations define our identities both as individuals and as species .... A sense of otherness, of distinctiveness, is the very basis of the consciousness of our individuality, and this consciousness, based in difference, is a constitutive element of what it is to be a human being. To attack any of these differences . . . is to attack the shared element of what makes us what we are as a species."

Michael Ignatieff, Lemkin's Word, NEW RePUBLIC, Feb. 26, 2001, at 27-28. 
characteristic, its "infinite plurality") 166 deprives all of us of various possibilities of being, 167 various ways of understanding the world. Diverse cultures, religions and ethnicities provide us with different and rich ways of understanding our world and ourselves as well. Genocide diminishes us in the literal and metaphoric sense. In the process of pursuing the fantasy of his pure community, the genocidaire disfigures the international community. To use an Arendtian term, crimes such as genocide and slavery make humans "superfluous" qua humans. ${ }^{168}$ While genocide is physical extermination, slavery is social death. ${ }^{169}$ In both cases, a particular group and its way of life are removed (physically or socially) from the community of humankind on the grounds that they are a threat (economically, socially, morally, and politically) to the pure community of the genocidaire or the slaveholder. Thus, both the genocidaire and the slaveholder (enslaver) are properly considered as enemies of humankind.

One aspect of the international community that is, therefore, imagined through the provisions of universal jurisdiction and the adoption of R2P is a community of diverse peoples and diverse ways of being. ${ }^{170}$ Indeed, the Millennium Declaration said as much

166 Hannah Arendt, Vies PolitiQues 1 (1986); see also HannaH Arendt, Men IN DARK TIMES 81-94 (1968).

167 The Mexican essayist, Octavio Paz, expresses this sentiment perfectly: "[E]very view of the world that becomes extinct, every culture that disappears diminishes a possibility." Octavio Paz, The Labyrinth of Solitude, cited in JAMES Tully, StRANGe MultiPlicity: CONSTITUtionAlism In AGE OF Diversity 186 (1995).

168 In a letter to Karl Jaspers, Arendt said this about radical evil:

"What radical evil really is I don't know, but it seems to me it somehow has to do with the following phenomenon: make human beings as human beings superfluous (not using them as mean to an end), which leaves their essence as humans untouched and impinges only on their human dignity; rather making them superfluous."

See Richard Bernstein, Are Arendt's Reflection on Evil Still Relevant? 70 REV. POL. 64, 67-68 (2008).

169 Orlando Patterson has powerfully made the argument of slavery as social death. See Orlando Patterson, Slavery And Social Death (1982). As Patterson observes, the slave is excommunicated from society. There is "natal alienation." Slavery does not simply use humans as means but it denies slaves their very humanity. Others too have seen genocide as social death. See Claudia Card, Genocide and Social Death, 18 HYPATIA 63, 65 (2003) ("The holocaust was not only a program of mass murder but an assault on Jewish social vitality.").

170 Lemkin seems to have made a similar point when he observed, "[n]ations [for him it means ethnic groups] are essential elements of the world community. The world represents only so much cultural and intellectual vigor as are created by its component national groups .... Our whole heritage is a product of the contribution of all peoples." RAPHAEL LEMKIN, AXIS RULE IN OCCUPIED EUROPE: LAWS OF 
when it observed that shared values lead to shared future "based upon our common humanity in all its diversity. . ."171

Offenses that are intended to cure us of that diversity, such as genocide, are the concern of all of us. Indeed, the International Criminal Tribunal for the Former Yugoslavia (ICTY) Appeals Chamber made the point well when it observed thusly: "Those who devise and implement genocide seek to deprive humanity of the manifold richness of its nationalities, races, ethnicities, and religions provide. This is a crime against all of humankind, its harm being felt not only by the group targeted for destruction, but by all of humanity." 172 Humanity is diminished by the actions of the genocidaire.

To summarize, the international community that is imagined through universal jurisdiction and R2P is not a community (federation) of states or simply a community of unmoored human persons organized as members of global human community, but rather it is a community of persons as bearers of and located in particular identities (cultures, ethnicities and religions). In this sense, the community imagined has both a universal (international community) and local (ethnic, national, racial, etc.) dimension to it. It is to make this point that Arendt described the Holocaust as a crime against humanity perpetrated on the body of the Jews. ${ }^{173}$ Through its intervention under universal jurisdiction and R2P to prevent or punish the genocidarie's attempt to establish his pure community by destroying other communities, the international community both affirms and defines the contours of the international community. The community it imagines is the antithesis of the genocidaire fantasy of a pure and superior community. The destructive fantasy of purity is countered with the reality of hybridity and plurality.

\subsubsection{Diversity and Vulnerability}

As I mentioned earlier, the United Nations Secretary General remarked at an international conference on the prevention of genocide that "[n]o part of the world can consider itself immune to the risk

Occupation, ANAlysis of GOVERnMent, Proposals fOr Redress 91 (1944). This means that the "destruction of a nation, therefore, results in the loss of its future contribution to the world." Id.

171 See U.N. Millennium Declaration, supra note 157, at 9 ; see also Id. at $₫ 6$.

172 Prosecutor v. Krstić, Case No. IT 98-33-A, Judgement, đ| 36 (April 19, 2004).

173 ARENDT, supra note 39, at 247. 
[of genocide]."174 Even though the statement might be considered too alarmist, the Secretary General has a point. The diverse international community, which is being shaped by globalization and greatly assisted by the communication revolution, is also becoming vulnerable due to these very factors. Globalization is leading not only to greater interconnection, but to intricate partitions as well. Many countries are increasingly getting fractured along ethnic and religious lines and the communication revolution is often used to cultivate and deepen these fractures, making this diverse international community vulnerable to destructive threats. The developments of fractures and the increasingly sophisticated nature of the means of destruction in the hands of genocidaries and terrorists make the international community vulnerable. So, the international community is both diverse and vulnerable to the threat of mass atrocities such as genocide. A global threat requires a global response. Universal jurisdiction and R2P are attempts to provide such a response. The international community's interest in preventing and punishing genocide rests on the proposition that we live in a world of diversity - ethnicity, religion, race, etc. - and genocide specifically targets that diversity. And because "almost all nations are patchworks of ethnic, racial and religious, and cultural groups," 175 an offense (such as genocide) that targets people precisely because of those characteristics threatens the very nature of the international community. The magnitude of the threat has increased as a result of new technologies - communication and technologies of destruction - which, as we saw in Rwanda, have made it easier to engage in purification quickly and efficiently.

\subsubsection{Defining (Imagining) the International Community From Above and From Below}

The argument thus far has been that, while we rightly focus on the responsibility that universal jurisdiction and R2P impose on individual states and/or on the international community to prevent genocide or to punish those who have engaged in genocide (the instrumental aspect of norms), we neglect or underemphasize another

\footnotetext{
174 Ban Ki-moon, Remarks at International Conference on Prevention of Genocide, supra note 42. (2004).

175 David Luban, A Theory of Crimes Against Humanity, 29 YALE L. J. 85, 138
} 
equally important role that these doctrines or norms play. They are also means through which we cultivate or constitute the international community as a community of character; they are processes by which we begin to define the nature or the identity of the international community of which we hear a great deal, but about which we are never quite clear.

As I noted earlier, identities - individual or group, institutional or personal-are constituted relationally. We define who we are in relation to the differences we perceive with others. It is no different with communities - national or international. Communities define their identities in relation to other communities. But of course the international community cannot define itself vis-à-vis other communities, for in the literal sense the international community includes all of us in all of our plural guises. There is no community to contrast itself with, for the assertion of its identity. I suggest that it is through norms such as those embodied in universal jurisdiction and $\mathrm{R} 2 \mathrm{P}$ - the notion that certain crimes such as genocide are an attack on all of us - that the international community begins to define the contours of its boundaries.

The idea of enemies of humankind provides the criteria that certain acts are simply beyond the permissible boundary of an international community of humankind. ${ }^{176}$ So, universal jurisdiction and R2P are simultaneously instrumental and constitutive. The international community on whose behalf they are invoked is at the same time being defended and constituted. R2P and universal jurisdiction are therefore performative in nature. By "performative," I mean to suggest that they constitute what they assert already exists. ${ }^{177}$ Through these two doctrines "humanity," that is "the status of being human," is defended while simultaneously constituted. In what sense is humanity constituted here? There are two ways. First, the notion of

176 Carlos Nino, in another context, described the Other outside the moral boundary of the community of humankind as "radical evil." See CARLOS SANTIAGO NinO, RADICAL EVIL ON TRIAL vii (1996).

177 The notion of performative discourse had its popular entry in J.L. Austin's work. See J.L. Austin, How To Do ThINGS WITH WorDS (2d ed. 1987). Austin famously argued that language cannot only describe things but actually do things. $I d$. at 94 . Thus, for example, when the President swings a bottle of champagne at a ship and says "I christen this ship the 'USS New Orleans,'" the President is not merely describing a christening, but performing one. See id. at 15. Not surprisingly, Austin called these sorts of verbal acts "performatives." See also PIERRE BOURDIEU, LANGUAGE AND SYMBOLIC POWER 223 (1991) (describing the how performative discourse attempts "to bring about what it asserts in the very act of asserting it."). 
"humanity" is constituted in the sense that assertions such as "genocide is a crime against the human status" aim at bootstrapping themselves into validity. Second, and more importantly, by taking responsibility for the crimes of others by holding them accountable and by establishing institutions through which we judge and repress genocide we "'share the onus of evil committed by others.' We become members of humanity." 178 That is, by assuming responsibility for genocidal acts or threats of genocide wherever they occur, we constitute humanity and the international community.

Once we understand that the two doctrines have both instrumental and constitutive roles, we then realize that the existence of these norms is important. Even when we think that these norms are not invoked as frequently as we would like them to be-when they have not closed the impunity gap-even when they are soft rather than hard responsibilities, and even when they do not provide the accountability desired by many. Their existence and the consensus around them starts building a culture, an attitude as to what the nature of the international community is and around what values it is constituted. They are processes through which the international community is imagined. The international community comes to life more on account of the substance to which it aspires than the entity it represents. The international community is a work in progress and the shared responsibilities in the context of genocide and other grave crimes contribute to that work in progress. Shared values and shared future require shared responsibility.

Shared responsibility could manifest itself in various ways. It could be discharged collectively, or it could be delegated to constituent parts from the bottom up (universal jurisdiction) or from the top down (R2P). ${ }^{179}$ This is indicative of the multiple ways in which the responsibility to protect, to correct and to define can be pursued. Universal jurisdiction is a bottom-up approach because it simply asks states to prosecute (or extradite) those accused of genocide if they are found in their territory.

Hannah Arendt thought that truly international crimes, such as genocide, should be tried by duly constituted international tribunals, not by a state court asserting universal jurisdiction or other (traditional) jurisdictional bases. She approvingly refers to a radio interview in Basel by Karl Jaspers that the crime against the Jews

178 See Luban, supra note 18 , at 320.

179 The International Criminal Court (ICC) is another example of a top-down intervention in terms of punishing genocidaires. 
was also a crime against mankind and consequently, the verdict can be handed down only by a court of justice representing all mankind. ${ }^{180}$ Arendt then goes on to assert, "insofar as the crime [against Jews] was a crime against humanity, it needed an international tribunal to do justice to it." 181 Why was it essential for Arendt that crimes such as genocide be prosecuted before an international tribunal (such as we have in the form of ad hoc tribunals) or the ICC? Her argument is that since the genocidal attack is an attack on all of us, only all of us, constituting ourselves in a form of international tribunal, can render a proper verdict. A trial before state courts courts of third countries - would, in her estimation, minimize the monstrosity of the event and limit the universality of the injury. Arendt's worry or complaint would apply not only when a third country invokes universal jurisdiction to punish a genocidaire, but even when a country invokes traditional sources of jurisdiction such as the nationality and passive personality principles to prosecute accused genocidaires. ${ }^{182}$

One may also add to Arendt's observation a practical concern that there is a danger that state actors may not render just punishment for purely political or partisan reasons. That is, universal jurisdiction would be asserted not so much to punish a genocidaire, but to advance the political interest of the state asserting universal jurisdiction. ${ }^{183}$ The point of impermissible intervention becomes even more salient in relation to $\mathrm{R} 2 \mathrm{P}$ when the intervention is military. It

180 See ARENDT, supra note 39, at 247.

181 Id.

182 The nationality principle would authorize a state to prosecute a national who had committed genocide abroad, whether or not the genocide is carried out against members of a group to whichever country that group belongs. The nationality principle simply allows states to regulate the conduct of their citizens anywhere in the world. The passive personality principle, which is more controversial, allows states to assert jurisdiction over certain acts - such as genocide - that harm or intended to harm their nationals. During the Eichmann trial in Jerusalem, Israel controversially purported to assert passive personality jurisdiction. Whether or not the assertion of passive personality jurisdiction is proper is not our concern here, although it is fair to point out that critics point to the fact that there was no Israel at the time of the crime and even if Israel had existed these were citizens of another country. Arendt would have rejected it as improper on another ground, that the trial should be an international trial since the crime is a crime against all of us, not just the Jewish victims or Israel. See ARENDT, supra note 39, at 263.

183 Universal jurisdiction could, for example, be used to intimidate the state from which the accused hails, especially if the accusation is that the government of the state (which is still in power) was involved in the genocide. 
is sufficient to note here, however, that it is partly this fear that compelled heads of states and governments to signal that even non-coercive R2P intervention ought to be coordinated through the United Nations. ${ }^{184}$ Coercive intervention to prevent or to stop genocide is to be authorized by the Security Council only. ${ }^{185}$ As I have indicated earlier, making the Security Council the only port of call has enormous downsides. What the Council did, or more precisely failed to do, during the Rwanda genocide is a very good example of why it ought not to be the only port of call on threatened genocide. ${ }^{186}$

Although the establishment of international or intergovernmental tribunals would be desirable under certain circumstances, I believe it would be a mistake, as Arendt would have it, to restrict the punishment of genocide to jurisdiction of such tribunals. First, the partiality or bias of international tribunals themselves is not always beyond reproach. 187 Second, for various reasons there are times

184 As the ICISS Report indicates, military intervention is the last resort after "appropriate diplomatic, humanitarian and other peaceful means . . . to protect populations from genocide, war crimes, ethnic cleansing and crimes against humanity .... [The international community] is prepared to take collective [coercive] action, in a timely and decisive manner, through the Security Council, in accordance with the Charter, including Chapter VII, on a case by case basis and in cooperation with relevant regional organizations as appropriate, should peaceful means be inadequate and national authorities are manifestly failing to protect their populations from genocide, war crimes, ethnic cleansing and crimes against humanity." ICISS, supra note 109, at 139.

185 Id. at xi.

186 See Power, supra note 11, at 43 (reporting that the Security Council drastically scaled down the UN Peacekeeping force during the height of the genocide when many Tutsi were in fact getting saved from slaughter because of the deterrence and cover the peacekeeping force was providing. Referring to this action Power notes, "The UN Security Council made a decision that sealed the Tutsi's fate and signaled the [Hutu] militia that it would have free rein.").

187 Many African leaders and political actors often complain that the International Criminal Court often targets Africans leaders or public officials for special attention and prosecution. There is some truth to that. Two sitting African presidents - presidents of Kenya and Sudan - have been indicted by the ICC. And one former president (Charles Taylor of Liberia) is convicted by an international tribunal and is in jail. Indeed, African countries have been talking about withdrawal from the Rome Statute since 2009. Dapo Akande, Is Kenya Pushing for a Mass African Withdrawal from the ICC? EUR. J. INT'L L: TALK (Jan. 14, 2011), available at https:/ / www.ejiltalk.org/is-kenya-pushing-for-a-mass-african-withdrawal-fromthe-icc/ [https://perma.cc/K9ZE-B382]. During its extraordinary October 2013 session in Addis Ababa, the African Union adopted and issued a document entitled "Decision on Africa's Relationship with the International Court" in which AU affirmed its "unflinching commitment" to fight impunity, but also expressed concern about what it called "the politicization and misuse of indictments against African leaders." African Union Decisions and Declarations, Extraordinary Session of the 
when international or intergovernmental tribunals are not available either to correct or to remedy a violation. ${ }^{188}$ There is no compelling reason why perpetrators of genocidal crimes should continue to move freely when that crime has brought untold sorrow to direct victims and has diminished the international community by wiping out or by attempting to wipe out a way of being from the face of the earth. Indeed, that was the view of three judges of the International Court of Justice in Democratic Republic of Congo v. Belgium (Arrest Warrant). 189

Third, as a normative matter, there is something to be said about constituting the culture of the international community from the bottom up or from the outside in. A community that develops as a result of wider participation of the constituent parts (which universal jurisdiction promises to provide) may be more defensible and more legitimate. This is so partly because the specific application of the principle of universal jurisdiction by various states would allow for experimentation and adaptation, providing a glimpse of what works and how it works. ${ }^{190}$ Indeed, the notion of universal jurisdiction would gesture simultaneously to the federal notion of pluralism

African Union, Decision on African Relationship with The International Criminal Court (ICC), Au Doc. Ext/Assembly/AU/Dec.1 (Oct. 12, 2013), available at http://www.coalitionfortheicc.org/documents/Ext_Assembly_AU_Dec_Decl_12Oct2013.pdf [https://perma.cc/EB77-V4HZ].

188 Thus, for example, for the ICC to prosecute a person accused of genocide, either the country of which the accused is a citizen should have ratified the Rome Convention which established the Court and its jurisdiction or, if the country is not a signatory, the Security Council, under its Chapter VII authority, has to refer the issue to the Court to investigate and prosecute, if warranted. Of course, the Security Council could do what it did in relation to Rwanda and the Former Yugoslavia establish an ad hoc tribunal in relation of allegation of mass crimes in a particular country. But it may be that none of the above options are available. It might be that the country of which the accused is a citizen has not signed and ratified the Rome Convention and that the Security Council is deadlocked and unable to exercise one of the two available options for peripheral political reasons. Or, the resources may not exist to establish the ad hoc tribunals. Under those circumstances, universal jurisdiction (the bottom up model) becomes the only option if the country that has the primary responsibility to protect and to remedy is unable and unwilling to perform that function.

189 Arrest Warrant of 11 Apr. 2000 (Dem. Rep. Congo v. Belg.), 2002 I.C.J. 3, q 51 (April 11) (joint separate opinion of Judges Higgins, Kooijmans, and Buergenthal).

190 I am here simply restating for a different purpose the classic argument in defense of federalism. John Stuart Mill refers to this as "experiments in living," which allows the citizens to learn from the experiences of other sub-units (in this case nation-states) as to how the norm fares as it is applied in different circumstances. JOHN STUART MILL, UTILITARIANISM AND ON LIBERTY: INCLUDING 'ESSAY ON 
and the universal ideal of cosmopolitanism. It in fact links the two, each acting on and shaping the other.

However, it is undeniable that both in relation to universal jurisdiction and R2P (especially R2P), the risk of impermissible intervention is real and we must continue to seek to develop limiting principles. 191 How would one minimize impermissible interventions by individual states or regional groupings either to prevent or to correct crimes against all of us, such as genocide? First, the fact that states or groupings would be intervening in relation to a small set of extreme human rights abuses such as genocide would, of course, reduce the frequencies of impermissible interventions. We must resist the call that intervention under these two doctrines be wide open in relation to a large spectrum of human rights violations. But even that limit clearly is not sufficient. Second, and in addition, I think we should require that intervention be permitted only to the extent that interveners adhere to internationally accepted definition or description of those crimes (in our case, genocide). After all, it is on behalf of all of us that interveners both at the front (R2P) and back (universal jurisdiction) ends claim to be acting. Thus, for example, if a state wants to prosecute an individual for genocide under universal jurisdiction, that state needs to have adopted the international definition of genocide. ${ }^{192}$ The same is true for a state or group of

BENTHAM' AND SELECTION FROM THE WRITINGS OF JEREMY BENTHAM AND JOHN AUSTIN 152 (Mary Warnock ed., 2d 2003) (1859).

191 See Maximo Langer, The Diplomacy of Universal Jurisdiction: The Political Branches and the Transnational Prosecution of International Crimes 105 AM. J. INT'L L. 1, 41-44 (2011) (concluding, after examining all contemporary cases based on universal jurisdiction, that there were no patterns suggesting that prosecutions were being pursued for purposes of intimidating another state or attacking its policy. In fact, the cases that made it to trial were apparently very strong.).

192 During the drafting of the Genocide Convention, there was disagreement as to whether "political groups" should be added to the list that includes national, ethnic, racial, and religious groups, as those whose intentional destruction will lead to the crime of genocide. Ultimately, the drafters decided to omit political groups from the list. However, there are some countries that have decided to include "political groups" in their national genocide statutes, statutes often meant to implement the international obligation under the Genocide Convention. Colombia and Ethiopia are two examples of countries that have included political groups on the list. See The Crime of Genocide in Domestic Laws and Penal Codes, PREVENT GENOCIDE INTERNATIONAL, http://www.preventgenocide.org/law/domestic [https://perma.cc/949W-UHT9] (last visited April 30, 2015). My worry about the inclusion of political groups is that dictatorial regimes, such as the one in power in Ethiopia, have used the threat of genocide to silence any political attack on political parties that happen to be part of the governmental coalition. To me, the inclusion of political groups seems to have more downsides than upsides. There are times when there is an overlap between a political group and an ethnic group, but in such 
states that wishes to intervene to protect a population that is being threatened with genocide. To the extent that the right to intervene presupposes application of a standardized definition, it is reasonable to assume that the possibility of manipulative use of the substance of a particular crime will decrease. 193

Third, the intervention would be permissible only when the primary responsibility holder is unable or unwilling to discharge its responsibility. Indeed, both universal jurisdiction and R2P (especially R2P) are explicitly premised on that assumption. ${ }^{194}$ We need to emphasize this point. Secondary responsibility comes at the end of a process where various means at various stages have been utilized in an attempt to make the discharge of secondary responsibility unnecessary.

Viewed this way, secondary responsibility to protect or to correct in relation to genocide (and other mass atrocities) is not an event. It is the end of a process. The sooner we learn that lesson, the better off we will all be. More importantly, the better off those on whose behalf we seek to intervene will be. Some have argued that the prospect of intervention through $\mathrm{R} 2 \mathrm{P}$ and universal jurisdiction is likely to make states reluctant to volunteer that they have a genocide problem. That is, they are likely to minimize the gravity of the situation for fear of collective or unilateral intervention. ${ }^{195}$ This is not an unreasonable fear. Sudan clearly denied that there was anything close to genocide in relation to the conflict in Darfur. Serbia

circumstance an attack on the political group (if part of an attack on an ethnic group) could be easily brought within the definition of destroying "in part, or in whole" the ethnic group, hence making the inclusion of "political groups" as a separate category unnecessary.

193 See, e.g., the Ethiopian Penal Code's definition of genocide and crimes against humanity. Ethiopian Penal Code art. 281. The specific article merges genocide and crimes against humanity into one offense and applies the international definition of genocide to that combined offense. The offense of crimes against humanity is essentially deemed to be a form of genocide. Not only does the penal code article deem crimes against humanity a genocide, but its definition of genocide is contradictory to the internationally accepted definition to the extent that it includes political groups on the list. The government has relied on this article to intimidate political opposition by charging and convicting opposition parties with genocide for criticizing the ruling party. I have dealt with this issue on a Voice of America radio interview on genocide. Interview with Dr. Adeno Addis (May 31, 2006), available at http://amharic.voanews.com/audio/2149237.html.

194 There is a strong expectation that if a state where the offense took place or is taking place wishes to prevent and or prosecute, then other states must defer to that state. See INAZUMI, supra note 102, at 178-95.

195 De Guzman, supra note 140, at 35. 
was not particularly eager to announce that there was anything resembling genocide during the Balkan conflicts. Yet, I think the worry is misplaced. First, there is no reason to believe that states would act differently were it not for the existence of these doctrines. It is unlikely that Serbia and Sudan would have been more forthcoming if R2P or universal jurisdiction had not existed. After all, these were regimes which would have minimized human rights violations across the board, whether or not a violation would lead to outside intervention. Second, it would likely be too late for the international community to perform its preventive functions if it were to rely on information coming out of the government offices of the target state alone, for often when there is a genocide the government has been implicated either as a participant or as tacit supporter of the perpetrating group. Third, there are in fact many non-government organizations that are engaged in genocide watch. ${ }^{196}$ Those organizations need to be strengthened. The United Nations system, as well as regional systems, need to develop early warning systems that do not entirely rely on governments to alert them to impending threats of genocide in their countries. ${ }^{197}$ Regional and United Nations early warning systems would draw from and benefit a great deal from similar national systems, especially from those major countries with the resources to establish such systems. ${ }^{198}$

196 See, e.g., The International Alliance to End Genocide, GENOCIDE WATCH, http://www.genocidewatch.org/genocide/whatisit.html

[https://perma.cc/9ZS7-NQUN].

197 Within the United Nations, a joint "Office for Genocide Prevention and $[\mathrm{R} 2 \mathrm{P}]$. . .helped establish institutional foundations for a deepening global consensus by clarifying the concept ... and engaging member states in detailed dialogue about its implementation." Bellamy, supra note 121, at 177.

198 In 2011 President Barack Obama issued Presidential Study Directive 10 Presidential Directive on Mass Atrocities - and he subsequently took other steps, the purpose of which to strengthen the ability of the United States to foresee and prevent genocide and other mass atrocities, utilizing the full range of tools available to the United States - diplomatic, economic or military. Presidential Study Directive on Mass Atrocities, White House OfFICE OF THE Press SeCretary (Aug. 4, 2011) available at http://whitehouse.gov/the-press-office/2011/08/04/presidential-studydirective-mass-atrocities [https:/ / perma.cc/ZA9R-B92L]. In Presidential Directive 10, the President noted, "[s]ixty six years since the Holocaust and 17 years after Rwanda, the United States still lacks a comprehensive policy framework and a corresponding interagency mechanism for preventing and responding to mass atrocities and genocide. This has left us ill prepared to engage early, proactively, and decisively to prevent threat from evolving into large scale civilian atrocities." Id. The U.S. Atrocities Prevention Strategy has been referred to as one that "fills a huge gap." Daniel Sullivan, Best and Worst of Genocide Prevention in 2012, UNITED TO END 
The Secretary-General of the United Nations has a special adviser on the prevention of genocide. Established in 2004, the Office of the Special Adviser on the Prevention of Genocide was created in the wake of the violence in Rwanda and the Balkans to serve as an early warning system to impending genocides so as to diminish the prospect of a genocidal outbreak. ${ }^{199}$ Part of the function of the office is to collect information from the U.N. system on serious human rights violations that may lead to genocide if not prevented or halted, to warn the Secretary-General, and through him, the United Nations Security Council of situations that could lead to genocide, and the like.200 The office has done its bit to warn about threat of genocide in various countries but a more robust early warning system would have to include the active participation of various civil society groups as well. As the first adviser, Juan E. Méndez noted, the office "cannot be regarded at present as universal and early-action mechanism for the prevention of genocide worldwide, but rather an effort to improve the United Nations' response to situations of potential massive violations of human rights and humanitarian law that have an ethnic, racial, religious or national character. This is an effort that requires strong support from Members States, NGOs, academia and others." 201

\section{THE INTERNATIONAL COMMUNITY AND GENOCIDE WATCH: RESPONSIBILITY TO PROTECT AND CIVIL SOCIETY}

When we talk about R2P we often think of the role of the United Nations and national governments. It is true that in terms of mili-

\footnotetext{
GENOCIDE (Dec. 31, 2012), http://endgenocide.org/best-and-worst-of-genocideprevention-in-2012/ [https://perma.cc/V7V8-Z796].

199 See generally Payam Akhavan, Report on the Work of the Office of the Special Adviser of the United Nations Secretary-General on the Prevention of Genocide, 28 Hum. RTS. Q. 1043. 1044-1047 (2006).

200 The office was established pursuant to Article 99 of the U.N. Charter and Security Council Resolution 1366 of 2001 which expressed the Council's commitment to "save people from raves of armed conflicts" and towards that end expressed "its willingness to give prompt consideration to early warning or prevention cases brought to its attention by the Secretary-General." (para. 5). See also Juan Méndez, Possibilities for Genocide Prevention, in EXPLAINING DARFUR: LeCTURES ON THE ONGOING GENOCIDE 49-60 (Fouad Ibrahim, intro. 2006).

201 Méndez, supra note 200, at 50-51.
} 
tary intervention to prevent or stop genocide, it is the United Nations and governments which would be playing central roles. While protection is first and foremost the responsibility of states and secondarily the responsibility of the United Nations, we often forget that there is a crucial role for another component of the international community - civil society.202 By civil society, I mean to refer to both international and national human rights NGOs which can contribute to the prevention of genocide by, among other things, providing information that alerts relevant international actors about the condition in a particular country or society to ensure that those societies are watched carefully. ${ }^{203}$ As I noted earlier, many countries are or ought to be on genocide watch, for they exhibit many of the conditions that prevail prior to genocidal events. I mentioned earlier that there are in fact non-governmental agencies that are engaged in monitoring countries and regions for any signs of the threat of genocide.204 Strengthening the capacities of those organizations, especially local organizations, to perform the important function of collecting information for purposes of early warning should be part of the international community's secondary responsibility to protect. ${ }^{205}$

202 See Roberto Belloni, Civil Society and the Responsibility to Protect, 28 GLOBAL SOCIETY 158, 159 (2014) ("A strong and active civil society can provide both a positive contribution to the adoption and implementation of R2P norms and be a bulwark against the spread of violence.").

203 I must note here that Intergovernmental Human Rights Organizations (IHRO) such as the UN Human Rights Committee and the Human Rights Council also play a very significant role in terms of reports they may have on the conditions of human rights in a particular country which may signal to the international community that conditions for mass atrocities prevail and conditions need to be monitored.

204 See GENOCIDE WATCH, http://genocidewatch.net/ [https://perma.cc/7ZPU-5MMH] (last visited Mar. 2, 2017). There are good reasons for establishing a genocide watch and alert system within the UN General Secretariat. Some of the established international human rights NGOs have been active and effective in terms of collecting information about impending threats of genocide. See Power, supra note 11, at 39 (stating "Human Rights Watch supplied exemplary intelligence [on the Rwanda Genocide].").

205 See MARGARET E. KECK AND KATHRYN SIKKINK, ACTIVITIES BEYOND BORDERS: ADVOCACY NETWORKS IN INTERNATIONAL POLITICS 22 (1998) (stating that the power of human rights NGOs comes not only because they are able to collect data and write reports on human rights conditions of countries, but also from the fact that they utilize the media to transmit and publicize those data and conditions making early intervention possible). See also Howard Ramos, James Ron, and Oskar N. T. Thomas, Shaping the Northern Media's Human Rights Coverage, 1986-2000, 44 J. OF PEACE RES. 385 (2007) (stating that international human rights NGOs do often influence the media from the developed world to cover issues that would otherwise not be covered, especially conditions in developing countries). 
But what are some of the conditions that would prevail prior to genocide, signaling an impending genocide? The immediate triggering or precipitating event that activates the relevant destructive boundary is often unpredictable. It might be a murder of a member of one group by a member or members of the hated group. It might be a rumor that the hated group is planning to attack.206 Or, as was the case in Rwanda, the leader of the ethnically fractured country is assassinated and rumor spreads that it was members of the hated ethnic group, the Tutsi, that slain the leader who is a member of the group (Hutu) that starts the genocidal attack. 207

Even though the immediate precipitating events might be hard to predict, it will be possible to assess what conditions have to exist for such events to be transformed as triggers of genocidal sprees. I shall mention some of the factors in the next paragraph, but let me add here one more thing about precipitating events. Donald Horowitz has argued persuasively that in terms of collective violence (in Horowitz's case it was what he called "the deadly ethnic riot"), the more ambiguous the precipitant factor the longer the lull period separating the precipitant event and the collective violence, whether a riot or a genocide. The reason for this is because the ambiguous event needs to be interpreted and that might require time. ${ }^{208}$ The precipitant event is by definition significant to the participants. It matters not that outsiders think of it as trivial.209

So, what conditions are likely to prevail before an impending genocide? First, Charles Tilly has shown in his comparative work on collective violence, such as ethnic riots, that the likely occurrence of genocide is not simply a matter of pre-existing hatred between the relevant groups, but it is also a question of the nature of the po-

206 For the nature and function of rumors in collective violence, see HorOWITZ, supra note 72 , at $74-88$.

207 The plane carrying the president, a Hutu, was shot down and rumors blamed Tutsi rebels. A Hutu militia attached to the government began the slaughter of Tutsi citizens. It might be worth mentioning here that quite often, perhaps even always, it is political activist and political entrepreneurs who accentuate the usthem boundary capable of leading to organize destructive violence. One sees that in cases such as the Rwanda genocide and the ethnic cleansing in Bosnia-Herzegovina.

208 See HorOWITZ, supra note 72, at 93 ("The more ambiguous the precipitant, the more it requires interpretation, and therefore the longer the interval may be.").

209 Id. at $270-71$. 
litical regime in control. Genocide is most likely to occur in countries whose regimes are low-capacity and undemocratic. ${ }^{210}$ Aristotle long ago pointed out that anger emanates from fear.211 To this Donald Horowitz adds that the triggering or precipitating event in genocidal attacks imparts proximity to that fear. ${ }^{212}$ In a country with a low-capacity undemocratic regime, the fear that the hated group will likely behave in the way the precipitating event indicates and with impunity is likely to be high, especially when the government is from the hated group. Conversely, Charles Tilly shows that genocide or group violence generally is least likely to occur under regimes that are high-capacity democratic, for grievances have outlets in the political process and the tendency of some activists to go the violent route would be effectively checked. There are two other types of regimes in this typology between the two extremes that I mentioned: low-capacity democratic and high-capacity undemocratic. There is more likelihood for group violence to occur under these regimes than under high-capacity democratic regimes, but the violence is likely to be very different from those in low-capacity undemocratic regimes. For example, in a high-capacity undemocratic regime, as was the case with Turkey's strong hold of the military not too long ago, collective ethnic violence is more likely to manifest itself in terrorism or insurgency (as is the case with Kurds) than genocide. 213 To put it simply, the international community (both intergovernmental and non-governmental organizations) should keep special watch on regimes where race, ethnicity or religion are salient

210 Charles Tilly, The Politics of Collective Violence (2003). Of course, it is even more likely to occur in a failed state. See Krain, supra note 15, at 581 ("Genocides and politicides are almost always a consequence of other types of State Failure such as civil war.").

211 ARISTOTLE, RHETORIC Book II, Chap. 5 (W. Rhys Roberts trans., Dover 2004); see also E.N. ANDERSON AND BARBARA A. ANDERSON, WARNING SIGNS OF GENOCIDE: AN ANTHROPOlOGICAL PERSPECTIVE 35-57 (2013).

212 HoROWITZ, supra note 72, at 548.

213 TILLY, supra note 210. In high-capacity and undemocratic regimes, "a much higher proportion of all collective violence pits governmental agents against citizens rather than setting groups of citizens at each other throats." Id. at 232. China may offer another example. Although China has discontented ethnic minorities such as the Uighurs and the Tibetans, it is unlikely that there would be sustained group violence among ethnic group within the country. What is likely is insurgency against the government. There is, for example, the East Turkestan Islamic Movement claiming to represent the interest of Uighurs, which the government of China has labeled a terrorist group. 
features of political and social life ${ }^{214}$ and where the regime is both dictatorial and low-capacity so as to pressure them both to democratize and to build their capacity to respond to challenges to the democratization process. ${ }^{215}$

Second, as I noted earlier, a regime which is low-capacity undemocratic and one that has formally organized the political community along ethnic, racial or national lines should be watched carefully, for the probability of identity-based violence that will develop into a full genocide is considerably high. In circumstances of this sort, what normally happens is that those identities are defined or viewed as if they were primordial making it a challenge to develop interethnic civic ties which are necessary conditions to reduce collective identity-based violence. Evidence shows that group violence is absent or less likely in political communities where there are interethnic civic ties - integrated sports associations or clubs, business or professional associations, political parties - which are likely to "kill rumors, remove misunderstandings, and often police neighborhoods." 216 The development and cultivation of such institutions will be a crucial step in the prevention of interethnic violence which might lead to full-scale genocide. The problem with dictatorial regimes (whether of the low-capacity or high-capacity kind) is that they often deny such groups political or civic space to cultivate the very ties that are meant to reduce tensions and suspicions among groups, mainly because those regimes survive by playing one group against the other. The international community (both in its intergovernmental and nongovernmental dimensions) needs to identify such regimes and put sufficient and sustained pressure on them to provide the necessary political and legal space for such interethnic

214 "Ethno-politics and state failure are closely linked .... Failed States threaten to become genocidal states." Christian P. Scherrer, Preventing Genocide: The Role of the International Community, PREVENT GENOCIDE INTERNATIONAL (Feb. 8, 2000), http://preventgenocide.org/prevent/scherrer.htm [https://perma.cc/V2DK99ZE].

215 Of course, there are times when leaders of high-capacity undemocratic regimes, such as Nazi Germany, itself engage in genocide, but under current circumstances that scenario seems unlikely.

216 Ashutosh VARshney, Ethnic Conflict and Civic Life: Hindus AND MUSLIMS IN INDIA 47 (2002). But one of course could ask whether the peace is the result of the interethnic ties or that the interethnic ties are the result of peace. The chicken and egg question might be raised in relation to the evidence here. 
institutions to flourish. ${ }^{217}$ And in the event that such pressure does not lead to change and that there was an imminent threat to genocidal attacks, the international community should be prepared to intervene to exercise its secondary responsibility.218 Evidence seems to be clear that "[one] approach that does seem to succeed at stopping the killing once it has begun is overt military intervention in favor of targets or against the perpetrator." 219

\section{CONCLUSION}

Genocide is unique among international crimes in the sense that both the intent that animates it and the manner in which the plan is pursued are group-based or group-oriented.220 The intent that propels it is one of destroying a group "as such." That plan is often carried out by a group (often assisted by a government) which, in the process of eliminating members of the victim group, attempts to simultaneously ensure the solidity and purity of itself as a group. Genocide is indeed an exercise in community building.

The international response to genocide through the two doctrines I have explored is obviously group based as well. The international community is responding as a community of humankind to protect or to sanction those who seek "to inflict[] great losses to

217 See Campbell, supra note 34, at 164-65 (showing that even in circumstances where there is "a high degree of ethnic conflict. . .genocide is normally absent where ethnic groups are functionally interdependent.").

218 Having a good early warning system or the capacity to predict as to whether a particular circumstance is pregnant with genocide, while good, is clearly not sufficient to prevent genocide. There has to be the commitment to act to prevent. Three months before the Rwanda genocide, beginning in January 1994, the Canadian general in charge of the United Nations contingent in Rwanda warned UN headquarters in New York that the situation in the country was of serious concern and that unless he received reinforcement there is going to be a blood bath. $\mathrm{He}$ pleaded not once, but several times. He sent five cables begging for help. The international community, including the Permanent Five, looked the other way. See Power, supra note 11, at 5.

219 Krain, supra note 15.

220 Some claim that all international crimes are group oriented. See Neha Jain, Individual Responsibility For Mass Atrocities: In Search of A Concept of Perpetration, 61 AM. J. COMP. L. REV. 831, 835 (2013) ("The main telling feature of an international crime as contrasted with its domestic counterpart is that it is inherently collective in nature, for the perpetrators as well as the victims."). 
humanity." 221 The loss is not just to a group or a nation; it is to "humanity" itself. In its 1951 advisory opinion, the International Court of Justice noted that the Genocide Convention "was manifestly adopted for a purely humanitarian and civilizing purpose ... [I]ts object on the one hand is to safeguard the very existence of certain human groups and on the other to confirm and endorse the most elementary principles of morality." 222 When the international community responds to the threat of the "very existence of certain human groups" and when it punishes those who have perpetrated the crime of genocide, it endorses "the most elementary principles" that are the foundation of an international community: a community of diverse peoples who are united in their very humanity and vulnerability. As the Millennium Declaration put it: shared values lead to shared future "based upon our common humanity in all its diversity. .."223

If genocide is indeed an attack on all of us, then not to respond to genocidal attacks or threatened genocide is to bring into question the validity or sincerity of the international legal claim that the genocidaire is an "enemy of all humankind." Even more worryingly, the lack of response sends a signal to others that genocidal attacks can go on with impunity. This last point was not lost on Hitler. Just before he invaded Poland in August 1939, he declared: "Our strength is in our quickness and our brutality ... . What the weak European civilisation thinks about me does not matter .... I have given the order and will have everyone shot who utters one word of criticism .... Thus for the time being I have sent to the East only my Death's Head units, with the order to kill without pity or mercy all men, women, and children of the Polish race or language. Who still talks nowadays of the extermination of the Armenians?" 224 Perhaps a forceful response by the international community during the Rwanda genocide 225 might have made genocidaires in the Balkans

221 See, Convention on Genocide, supra note 22, at pmbl.

222 Reservations to Convention on Genocide, supra note 31, at 23.

223 See U.N. Millennium Declaration, supra note 157, at 9 . See also id, at ๆ.6.

224 The quote was reported by The Times of London, Nov. 24, 1945 (emphasis added). See also New York Times, November 24, 1945; Hannibal Travis, Did the Armenian Genocide Inspire Hitler? Turkey, Past and Future, 20 MidDlE EAST Q. 27 (2013).

225 See Ban Ki-moon, supra note 42 ("Ladies and Gentlemen, In the face of the violence in Rwanda, the Security Council withdrew the UN peacekeeping operation, thereby taking away the sorely needed international 'eyes and ears' on the 
or in Darfur think twice before they engaged in genocidal acts. We will never know if forceful responses during the prior genocidal events would have prevented subsequent genocidal outbreaks, but we know for certain that a culture of impunity does not diminish the prospect or frequencies of genocidal attacks.

But this article has also argued that the international doctrines through which the international community responds (or is meant to respond) to the threat or the act of genocide-universal jurisdiction and $\mathrm{R} 2 \mathrm{P}$ - are not simply functional or instrumental. They are constitutive (performative) as well. They are processes through which the international community is imagined. The interests that are protected by these doctrines are not merely the interest of this or that group or this or that nation (of which members of the group are citizens), but rather they are interests of the international community as a whole. The injury that genocide inflicts is an injury to all of us. 226

How are universal jurisdiction and R2P performative? First, the assertion expressed by the two doctrines that "genocide is a crime

ground. The UN was also deeply tarnished by its actions and inactions at Srebrenica."). The United States, too, looked the other way, refusing to label the massacre as genocide, for fear that so labelling it would require it to intervene. Susan Rice, the National Security Advisor in the Obama Administration and at the time of the Rwanda genocide the Assistant Secretary of State for African Affairs [in the Clinton Administration], expressed that thinking astonishingly candidly. She said "If we use the word 'genocide' and are seen as doing nothing [in Rwanda], what will be the effect on the November [congressional] election?" Power, supra note 11 at 33. President Bill Clinton later (speaking to the crowd assembled at the Rwandan international airport) expressed regret for not having intervened earlier. "We have come here today partly in recognition of the fact that we in the United States and the world community did not do as much as we could have and should have done to try to limit what occurred." Id. at 3. The failure is said to have had an enduring impact on Clinton. He is said to have remarked that if the U.S. had intervened earlier it would "have saved at least a third of the lives that were lost." Bill Clinton: We Could Have Saved 300,000 Lives in Rwanda, CNBC (Mar. 12, 2013 at 1:15 PM), http://www.cnbc.com/id/100546207. Saving a third would have meant saving at least 300,000 people!

226 This is, of course, in contrast to our attitude to the violations of human rights that are not part of the universal jurisdiction or R2P list. Even though the international community seeks to hold primary responsibility holders accountable for the protection of all of the rights of individuals within their territories and under their jurisdictions, the human rights violations outside the universal jurisdiction and R2P list are not considered injuries to all of us. In an earlier article, I have referred to the international community's attitude toward those rights as individualist cosmopolitanism, and to its attitude towards rights and interests protected under universal jurisdiction and R2P as communitarian cosmopolitanism. See Addis, Imagining the International Community, supra note 136, at 159-60. 
against the human status, a crime against all of us," constitutes "humanity," as David Luban notes227, by aiming to bootstrap the idea of humanity into validity. Second, and more importantly, by invoking those doctrines to take responsibility for the crimes of others by holding them accountable for the crime of genocide, we "share the onus of evil committed by others. We become members of humanity." 228 That is, by assuming responsibility for genocidal acts or threats of genocide wherever they occur we constitute humanity and the international community. Luban is entirely correct when he noted, citing Arendt, that "belonging to humanity, or even creating humanity, is something that we $d o$, , 229 for humanity "exists only when we shoulder the demanding forms of cross-border responsibility." 230

227 See Luban, supra note 175 , at 87.

228 See Luban, supra note 18 at 320.

229 See id. at 319.

230 Id. "We take responsibility for the crimes of others by holding them accountable, and so the practical way we constitute humanity will conspicuously include the construction of new institutions to hold wrongdoers accountable." Id. at 320 . 